\title{
Carbon footprint in Higher Education Institutions: a literature review and prospects for future research
}

\author{
Karen Valls-Val' ${ }^{1}$ María D. Bovea ${ }^{1}[$ ] \\ Received: 14 December 2020 / Accepted: 23 July 2021 / Published online: 23 August 2021 \\ (c) The Author(s), under exclusive licence to Springer-Verlag GmbH Germany, part of Springer Nature 2021
}

\begin{abstract}
Higher Education Institutions (HEI) or universities, as organisations engaged in education, research and community services, play an important role in promoting sustainable development. Therefore, they are increasingly linked to the initiative of calculating their carbon footprint (CF), which is a tool to assess sustainability from the perspective of greenhouse gas (GHG) emissions. The aim of this study is to carry out a systematic review of the current situation of CF assessment in academic institutions by analysing different key elements, such as the time period, methodologies and practises, calculation tools, emission sources, emission factors and reduction plans. The review protocol considered articles published until March 2021. Of the articles reviewed, 35 are aimed specifically at calculating the CF of HEI, while the remaining articles consist of review, activity-specific CF assessment or GHG emission reduction articles. Clear differences have been identified when results are compared for the normalised $\mathrm{CF}$ (average of $2.67 \mathrm{t} \mathrm{CO}_{2} \mathrm{e} /$ student, ranging from 0.06 to 10.94) or the percentage of carbon offsetting, only considered in $14 \%$ of the studies and ranging from 0.09 to $18 \%$. The main reason for this is the lack of standardisation as regards the time metric (year, semester), functional unit (student, employee, area) and data collection boundary (scope 1,2,3), the emissions sources and emission factors, mainly for scope 3 (water consumption and treatment, waste treatment, office, ICT and laboratory consumables, commuting and travel, construction materials, canteens, etc.), and the inclusion or not of the effect of carbon offset projects to offset the CF (aim of the project and absorption sources and factors). However, despite the differences, a reduction over time is clearly observed. Therefore, CF in HEI requires further improvements and solutions to a number of challenges, including the definition of representative emission sources, the creation of a robust emission factor database and the development of tools/methodologies that cover all the needs of this type of organisation.
\end{abstract}

María D. Bovea

bovea@uji.es

1 Department of Mechanical Engineering and Construction, Universitat Jaume I, Av. Sos Baynat s/n, 12071 Castellón, Spain 


\section{Graphic abstract}

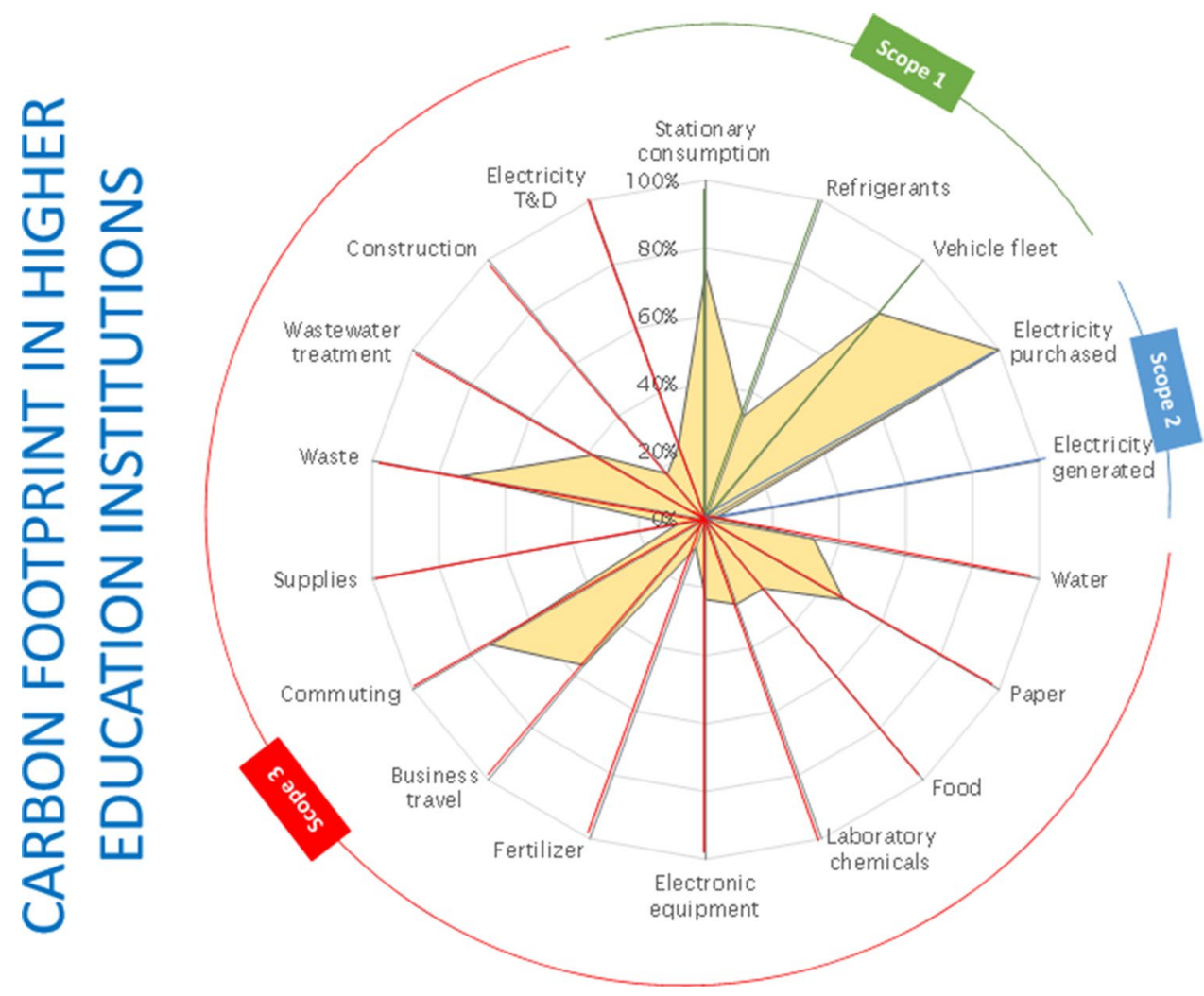

Keywords Sustainability $\cdot$ Greenhouse gas $\cdot$ University $\cdot$ Comparison $\cdot$ CF

\section{Introduction}

Academic institutions play a crucial and significant role in helping society to meet the climate and environmental challenges proposed by international frameworks, such as Green Deal (COM 640 2019) and the framework for achieving climate neutrality (COM 80 2020) focussed on achieving climate neutrality in the short/medium term. Higher Education Institutions (HEI), as organisations committed to education and research, play a significant role in preparing responsible graduates involved in maintaining sustainable development, and they themselves have to be an example for their students and staff as well as for society as a whole. For this reason, calculating, tracking and reporting their own carbon footprint $(\mathrm{CF})$ is a starting point from which to become sustainable organisations.

The term "carbon footprint" is defined by the IPCC Guidelines (2006) as "a representation of the effect on climate in terms of the total amount of greenhouse gases (GHG) that are produced, measured in units of $\mathrm{CO}_{2} \mathrm{e}$ as a result of the activities of an organization". GHG emissions can be calculated for each source using the following formula:

$E_{S}=A D_{S} \times E F_{S}$

where the GHG emissions from a specific source $\left(E_{S}\right)$ are obtained from the product between the activity data from that specific source $\left(\mathrm{AD}_{\mathrm{S}}\right)$, which represents a quantitative measure of the source expressed in units (for example litres of petrol or $\mathrm{kWh}$ of electricity), and its respective GHG emission factor $\left(\mathrm{EF}_{\mathrm{S}}\right)$, which is a coefficient that allows activity data to be converted into GHG emission. Once the total GHG emissions from all sources have been calculated, they are added up to quantify the total CF in units of carbon dioxide equivalent $\left(\mathrm{CO}_{2} \mathrm{e}\right)$. This is a common unit for describing GHG emissions, for any quantity and type of GHG it signifies the amount of $\mathrm{CO}_{2}$, which would have the equivalent global warming impact.

Although organisations contribute significantly to GHG emissions, methodological guidance for them is less developed and less prescriptive than for products (Robinson et al. 2015). There are different international standards for 
calculating the $\mathrm{CF}$ of organisations. Amongst others, the most notable regulatory frameworks are the GHG Protocol (2004), ISO 14064-1 (2006) and ISO/TR 14069 (2013), PAS 2050 (2011) and PAS 2060 (2014). Although initially they were applied to verify the requirements for quantifying GHG emissions within organisations under the Kyoto Protocol (2008), their use is currently becoming widespread in other types of organisations that are voluntarily interested in calculating and communicating their $\mathrm{CF}$.

Higher Education Institutions, also known as universities, are establishments devoted to post-secondary education and research that award academic degrees in different disciplines. Therefore, as organisations engaged in education, research and community services, they play an important role in sustainable development and the fight against climate change (Cordero et al. 2020). CF is a very useful tool for exercising a greater degree of control over activities that impact on the environment (Robinson et al. 2018) and also provides a baseline on which to evaluate the effect of future mitigation efforts on-campus (Letete et al. 2011).

Moreover, the role of HEI in sustainability is already recognised by different international declarations, such as the Talloires Declaration (TD 1990) or the Cre-Copernicus University Charta (Copernicus 1993), associations/networks, such as the CRUE's Sectoral Sustainability Commission (CRUE 2002), the Association for the Advancement of Sustainability in Higher Education (AASHE 2005), the American College and University Presidents' Climate Commitment (ACUPCC 2007), which was rebranded as the Carbon Commitment (CC 2015), the International Sustainable Campus Network (ISCN 2007) or the Global Universities Partnership on Environment for Sustainability (GUPES 2012), as well as rankings, such as the Times Higher Education-World University Ranking (THE 2004), the Sustainability Monitoring, Assessment and Rating System (STARS 2013) or the UI GreenMetric World University Ranking on Sustainability (GreenMetric 2010).

For these reasons, universities, as an example of sustainable organisations, should take a leading role in the fight against climate change and thus in the calculation, monitoring, reporting, reduction or even offsetting of their CF. However, as a preliminary step for calculating the CF of HEI, it is necessary to understand their activities that contribute to climate change by creating a greenhouse gas emissions inventory (Bailey and LaPoint 2016). HEI typically consists of a mixture of buildings used for classrooms, laboratories, offices, canteens, residences, etc. Some of them have their own power plants, transport circuits, water systems or health services, mainly depending on the number of students they host. Any of these activities have emission sources contributing to the $\mathrm{CF}$, which need to be identified and quantified. This task can become complicated depending on the type and size of the institution. In this study, the use of university buildings and the material needed to carry out academic activities are considered. Santovito and Abiko (2018) offered recommendations on how to prepare the GHG inventory, identified some relevant emission sources and allowed a better visualisation of the opportunities for GHG mitigation. Yet, there is no specific standardised methodology for conducting the inventory and calculating the GHG emissions generated for the case of educational institutions.

Several reviews can be found in the literature. Some of them are focussed on analysing methodological aspects of the CF calculation, Fenner et al. (2018) for the building sector or Durojaye et al. (2020) in general, highlighting both the lack of standardisation in spite of the different frameworks developed for that purpose. Others are specific reviews dedicated to specific sectors, such as construction/ buildings (Onat and Kucukvar (2020) for the construction industry, Che Muhammad Fatihi Hafifi Wahid et al. (2019) for highway developments and Schwartz et al. (2018) for refurbished and new buildings), population (Purwanto et al. (2019) for settlement activities and Heinonen et al. (2020) for consumptions in settlement, region, city or country), food and drink (Navarro et al. (2017) for wine and wineries, Brade and Brade (2014) for milk and milk products production, Rugani et al. (2013) for wine, Nijdam et al. (2012) for animal food and their substitutes and Pirlo (2012) for milk production), healthcare (Rizan et al. (2020) for surgical operations and Alshqaqeeq et al. (2020) for hospital services), metal (Nilsson et al. (2017) for $\mathrm{Cu}$ and $\mathrm{Zn}$ production from primary and secondary sources), tourism (Sun et al. (2020) for transport, accommodation, catering, shopping, entertainment, telecommunications, etc.), water (Cornejo et al. (2014) for water reuse and desalination) and Information and Communication Technology (ICT) (Grimm et al. (2014) for workplace hardware, server, networks and ITservices). However, no specific reviews have been done for educational activities, as Fig. 1 shows. So, this study fills this gap, encompassing research activity in $\mathrm{CF}$ in this field, from the date of publication of the first CF framework (2004), to the present (March 2021).

Although there are no general reviews related to this subject, the literature contains a few studies focussed on comparing the CFs of different HEIs belonging to specific associations in a specific geographical area. So that, Sinha et al. (2010) compared the CF from institutions that were signatories of the American College and University Presidents' Climate Commitment (ACUPCC) and Bailey and LaPoint (2016) compared the $\mathrm{CF}$ from nine universities located in Texas (USA). Both studies applied the Clean Air Cool Planet Calculator (CA-CP 2020) to compile and model the emission data from the institutions compared in each study. However, when trying to compare the $\mathrm{CF}$ from different studies, the scope, boundaries, emission sources, emission factors, etc. are specifically defined for each case study, making it 


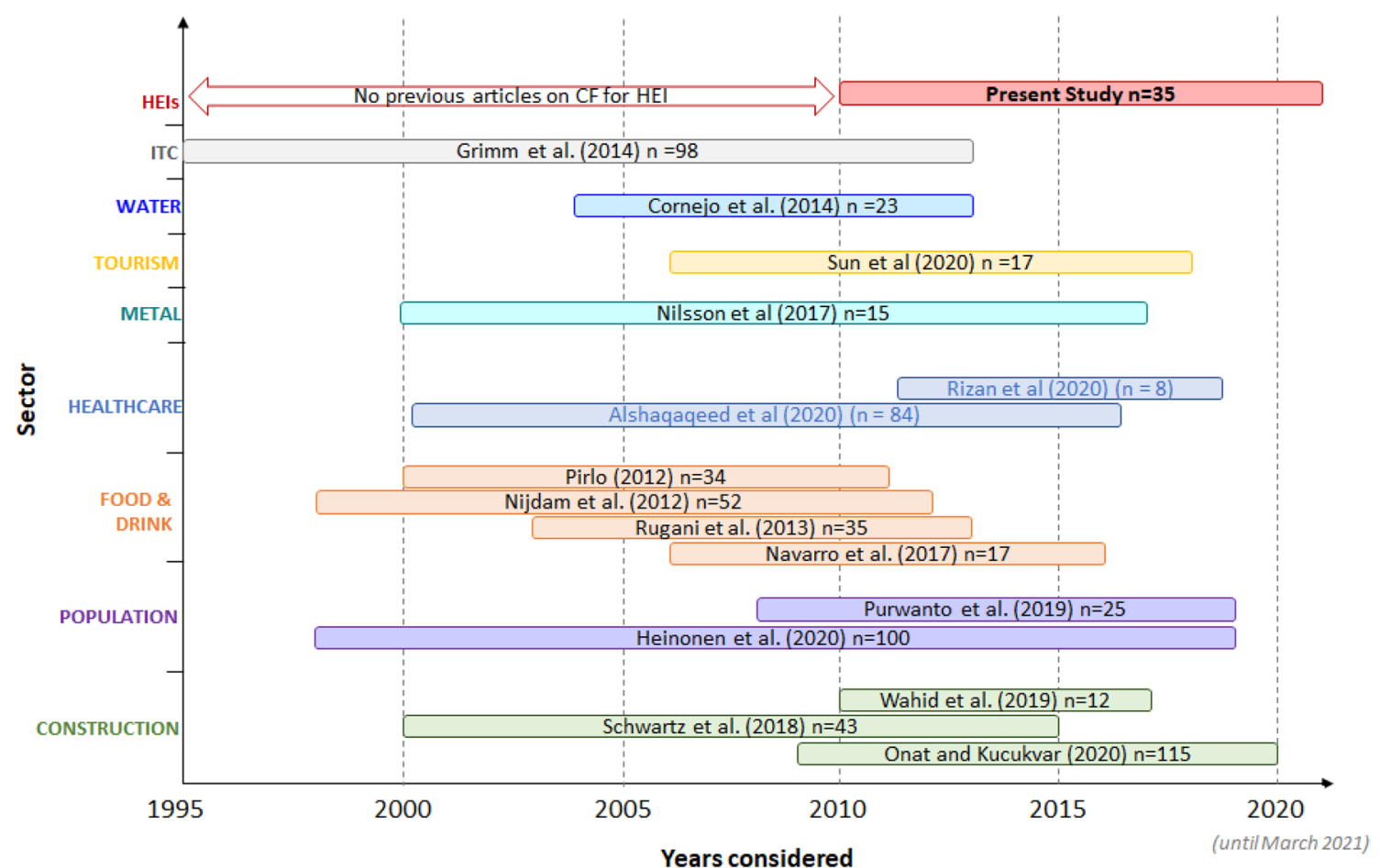

Fig. 1 Other reviews in the literature classified by sector and years covered ( $n=$ number of articles)

difficult to carry out comparisons amongst different HEIs. This fact highlights the lack of a common framework.

Taking into account this context, the aim of this study is to carry out a review of studies calculating the CF of HEI worldwide in order to identify the most common practises related to the methodological aspects of the calculation and to compare results. This will make it possible to establish a common framework that facilitates comparability of the studies. The paper is structured as follows: Sect. 2 presents a four-stage methodology used to select the studies under review and as the basis for comparing those studies in general terms, as well as their methodology and results; Sect. 3 presents the results obtained after applying the methodology; Sect. 4 discusses the results; and, lastly, Sect. 5 draws some final conclusions.

\section{Research methodology}

This systematic review follows a structure designed to achieve consistency, robustness and transparency in research. The methodology guides the selection of case studies focussed on calculating the CF in HEI and the evaluation rules to identify the information to be extracted. The research methodology has four stages, as shown in Fig. 2 and described below:
- Stage 1 aims to identify the literature focussed on quantifying the CF of HEI and whose content included fully detailed and defined case studies with a consistent methodology and results.

- Stage 2 includes the general mapping of the literature selected in stage 1, considering temporal aspects and the main descriptive characteristics of the institution under analysis (location, size, etc.).

- Stage 3 goes deeper into the analysis of specific aspects related to the calculation of $\mathrm{CF}$, that is, methodologies applied, goal definition, scopes, source emissions, etc.

- Stage 4 focuses on the comparison amongst the CF of the HEI analysed and the identification of the causes underlying the differences found.

\section{Results}

\section{Stage 1: identification of articles}

The Scopus database was used as the main search engine for selecting the literature, using "carbon footprint, university", "greenhouse, university", "carbon footprint, higher education" and "greenhouse, higher education" as strings in the article title and keywords. To avoid limitations due to the capacity of the database search, other sources, such 


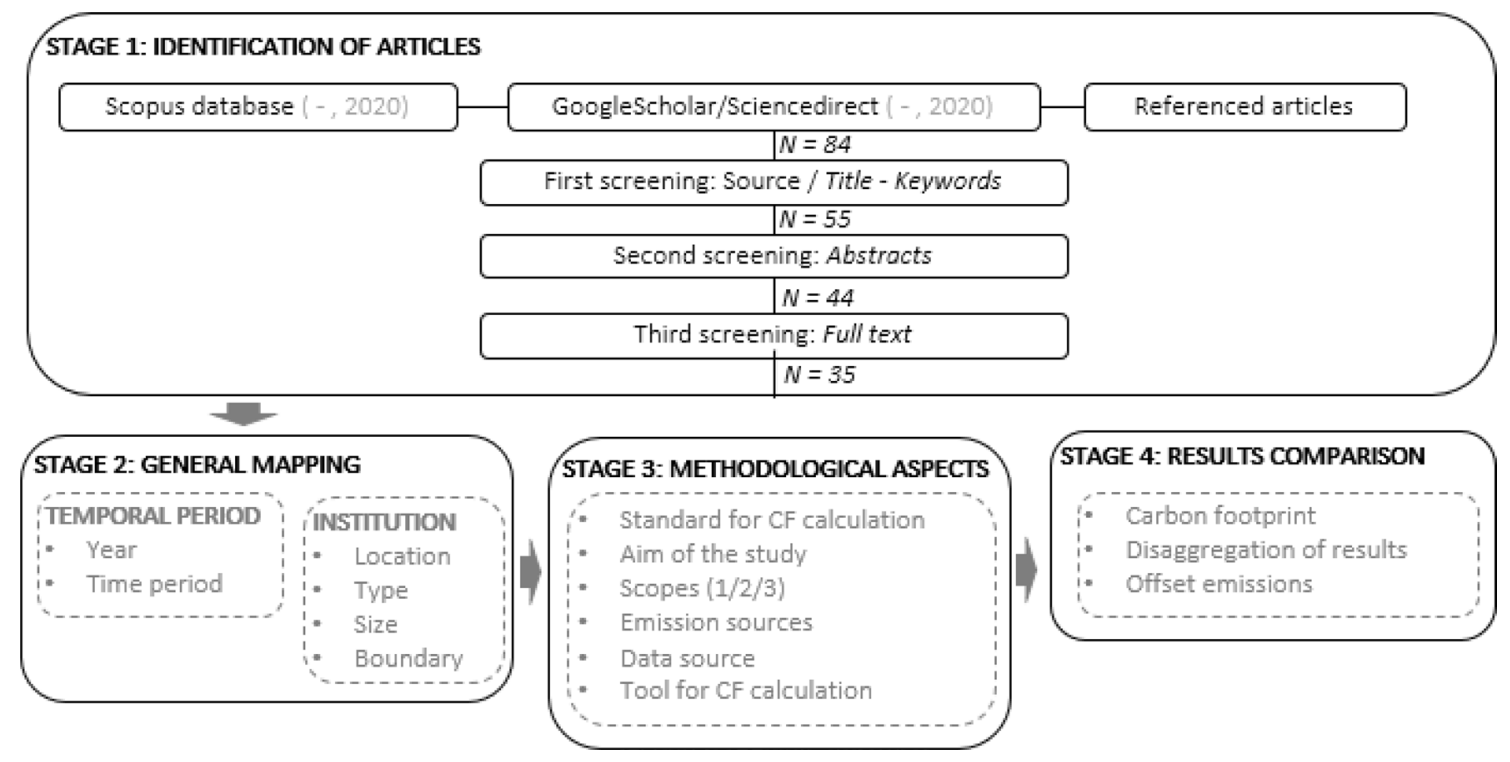

Fig. 2 Methodology

as GoogleScholar and ScienceDirect were used with these same strings to complete the list of articles to be analysed. In addition, the list obtained was completed with specific articles found in the list of references of those articles focussed on literature reviews. By applying this procedure, 84 articles were found. A first screening of the source title and article title/keywords resulted in the rejection of those that did not correspond to indexed research articles or conference papers, and those that did not focus on the calculation of the carbon footprint of HEI, respectively. In addition, duplicates were also rejected, thus reducing the sample to 55 articles. A second screening of the content of the abstracts was conducted and articles that were not aimed at calculating the carbon footprint of one or more HEI were excluded, thereby further reducing the sample to 44 articles. After a third screening of the full text, only articles that included fully detailed and defined case studies with a consistent methodology and results were included. A final sample of 35 articles was selected, as reported in Table 1. A descriptive content analysis was carried out, considering the aspects detailed in Fig. 2.

Other studies were not included in this review although they did calculate the $\mathrm{CF}$, because this calculation was linked to specific university activities. For example, Chung et al. (2014) and Sippel et al. (2018) calculated the CF due to some students' campus activities in Tajen University (Taiwan) and in the University of Applied Science in Konstanz (Germany), respectively, while Kulsuwan et al. (2019) only took into account the students' electricity consumption in Mahidol University Amnat Charoen Campus (Thailand). Barros et al. (2018), Pérez-Neira et al. (2020) and Rao et al. (2017) calculated the CF of transportation habits in the
Federal University of Technology (Brazil), the University of León (Spain) and the Symbiosis International University (India), respectively, while Beardsley and Morton (2009) did the same for university sponsored air travels. In addition, Schwarz and Bonhotal (2018) determined the CF of a compost facility at Cornell University (USA), Stephan et al. (2020) examined the embodied CF in materials on the Parkville campus of the University of Melbourne (Australia) and Song et al. (2016) calculated that of scientific publications at Dalian University of Technology (China). On the other hand, Filimonau et al. (2021) compared the carbon intensity of on-campus and off-campus higher education, taking advantage of the unique opportunity of the COVID19 pandemic.

\section{Stage 2: general mapping}

As a starting point of the review, a general mapping of the 35 research papers reported in Table 1 was carried out by analysing the following general aspects related to the time period analysed and the main characteristics of the institution:

- Location of university It can also be observed in Fig. 3 that studies are distributed all around the world: $20 \%$ in Europe, 34\% in Asia, 6\% in Africa, 6\% in Oceania, and $23 \%$ and $11 \%$ in North and South America, respectively. The CF can be highly conditioned by the climatic conditions of the location of the higher education institution, so it is necessary to subsequently analyse the influence of its value with the location of the HEI. 
- Type of institution $86 \%$ of the studies correspond to public higher education institutions, $11 \%$ to private ones and the remaining 3\% to national ones. Therefore, a greater involvement of public higher education institutions is observed.

- Year analysed 34\% of the studies were conducted between 2000 and 2010, while the remaining $66 \%$ were carried out in the decade 2011-2020. As Fig. 3 shows, there is a significant increase in the number of articles published over the years, mainly in 2020 . This may be due to the fact that HEI is more aware of environmental issues and also their commitment to contribute to their decarbonisation as a sustainability strategy.

- Time period analysed Some studies calculated the carbon footprint for one academic year (29\%), while others did so for a fiscal year (68\%) and only one of them considered a single semester (Kandananond 2017). The results are lower when only one semester is calculated, so this study is not comparable with the rest.

- Boundary $43 \%$ of the studies analyse the whole institution (I, in Table 1), $48 \%$ analyse only one campus of the institution ( $\mathrm{C}$, in Table 1), while the remaining 9\% analyse only one building/school (B, in Table 1). It is thus observed that universities prefer to carry out the analysis of a single campus, as the different campuses often act independently.

- Size of the institution As Table 1 reports, two main parameters are considered for measuring the size of the institution: people and area. The parameter people is considered in $86 \%$ of the studies, although it is measured according to three different variables: students in $77 \%$ of the studies, employees in $57 \%$ of the studies and per capita (as the sum of students and employees) in $66 \%$ of the studies. The parameter area is considered in $43 \%$ of the studies. This aspect is important as it allows a comparison of CF to be carried out amongst different institutions.

\section{Stage 3: methodological aspects}

A content analysis of the selected articles was performed to identify the main methodological aspect followed in each one. This was a feedback process defining the criteria used to classify each article in order to support the results and discussion of findings. The methodological elements evaluated for each article selected are reported in Table 1 and analysed below:

- Standard applied for the CF calculation As described in the introduction section, there are different international standards for calculating the CF. Only $17 \%$ of the studies reviewed fail to indicate the standard used as a basis. Of the rest, 54\% use GHG Protocol (2004), 20\% use (IPCC Guidelines 2006), 11\% use ISO 14,064-1 (2006), and PAS 2050 (2011) is used by Budihardjo et al. (2020) and Thurston and Eckelman (2011).

- Aim of the study Although the main aim of all the studies is to evaluate the CF of the institution/campus or building/school, three different secondary objectives were also identified. Some studies analyse the evolution of emissions over time (40\%) while the rest only calculate emis-

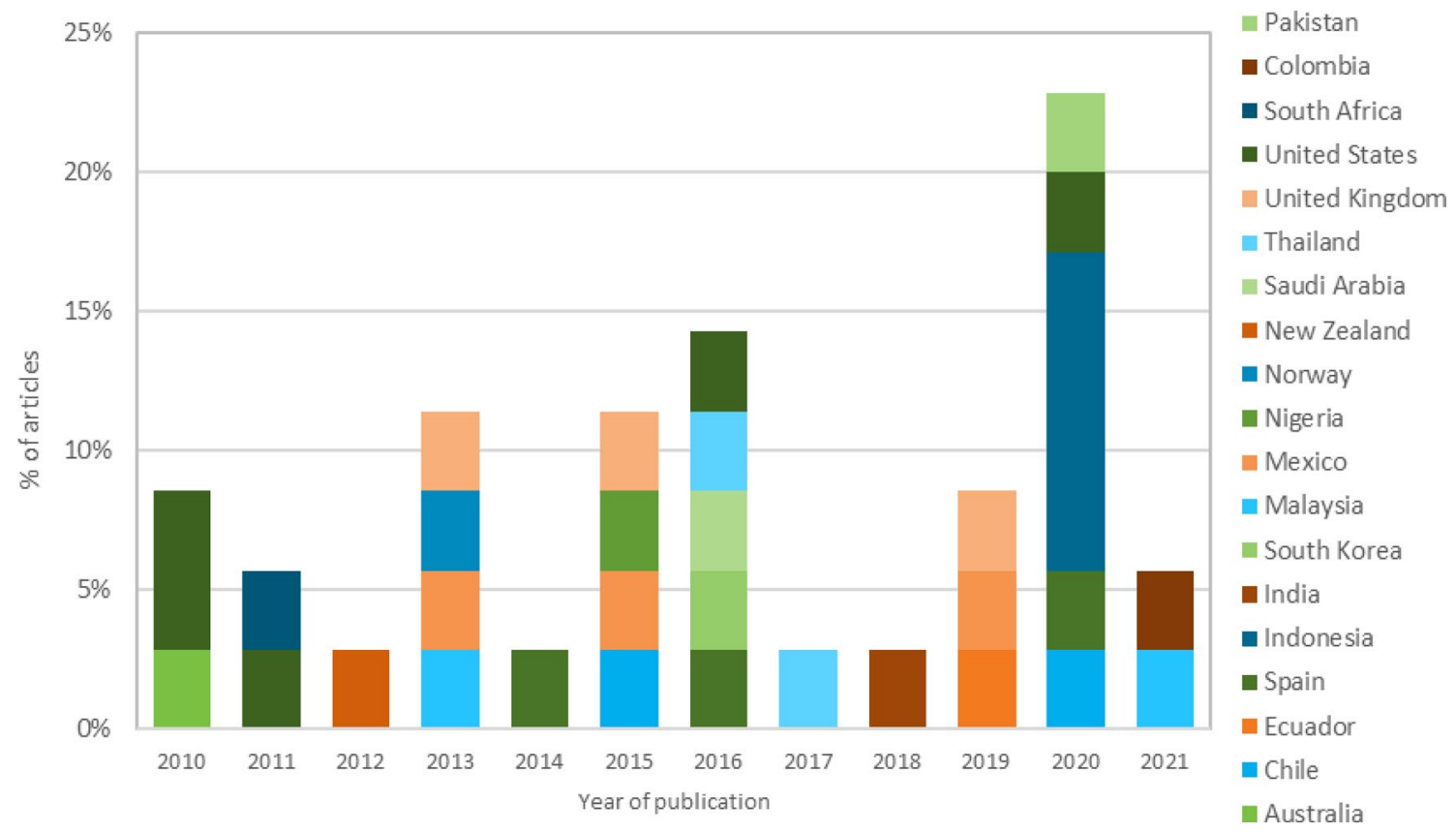

Fig. 3 Temporal evolution of the literature related to calculation of CF of higher educational institutions, by country 


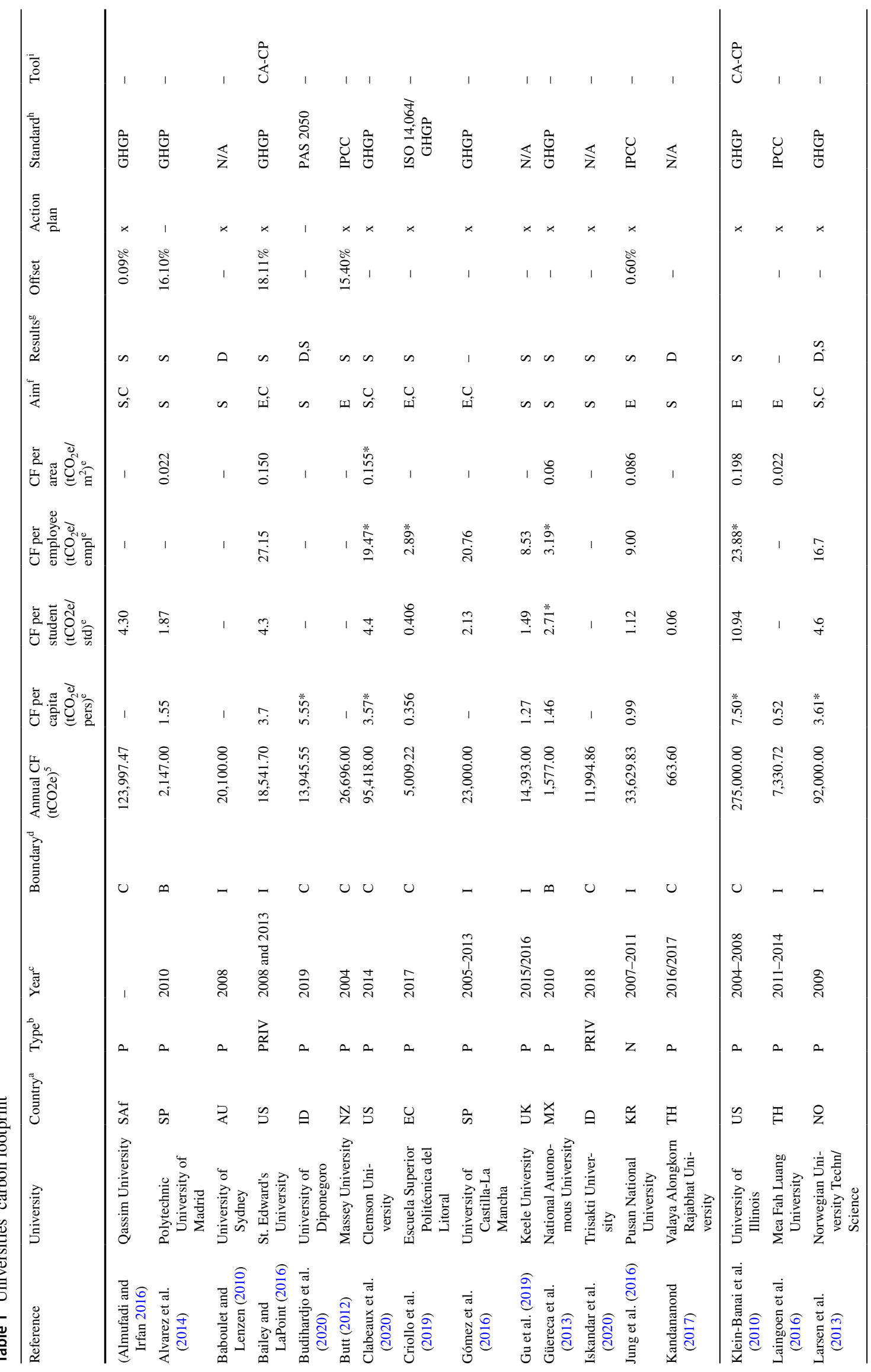




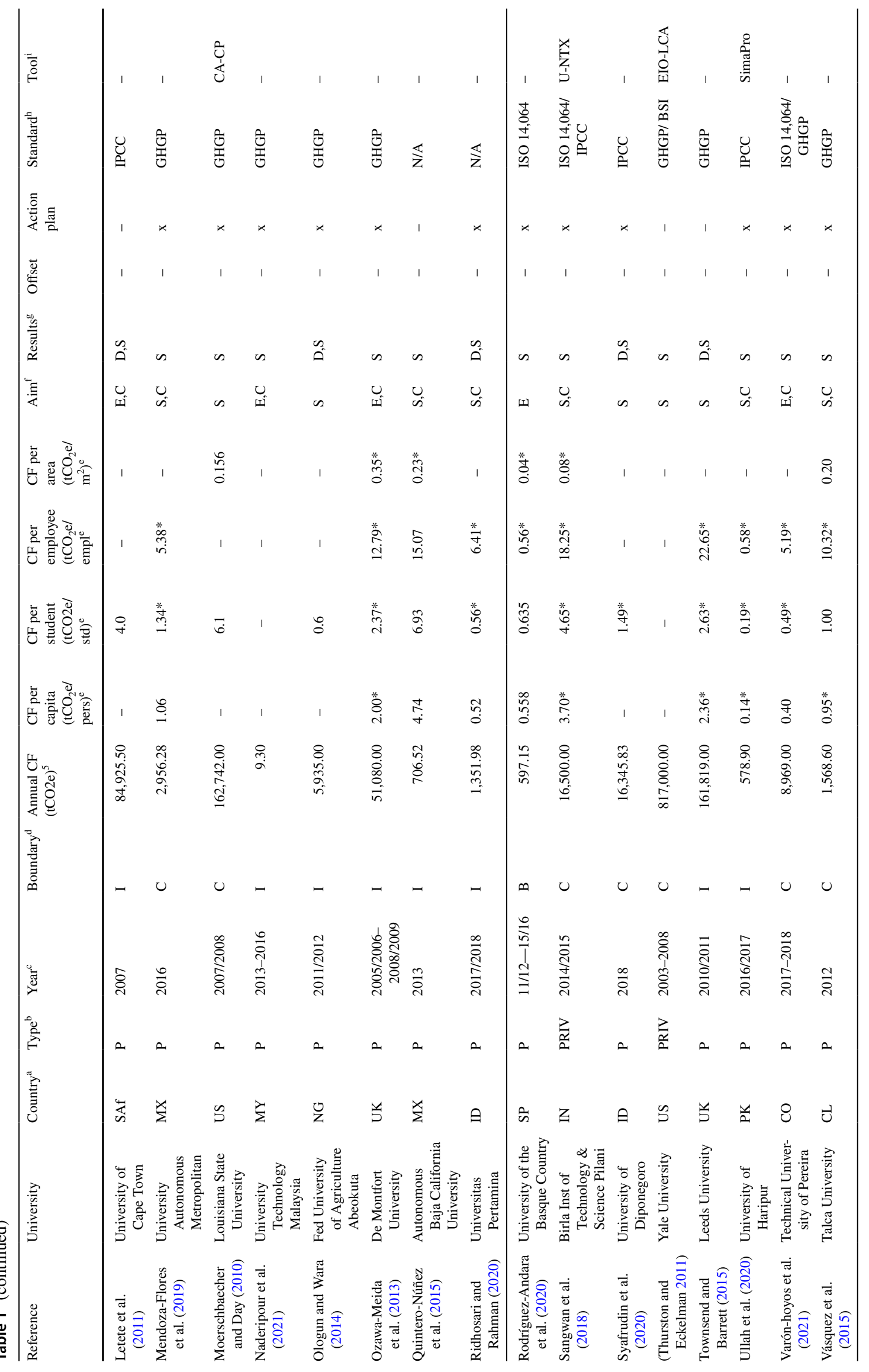




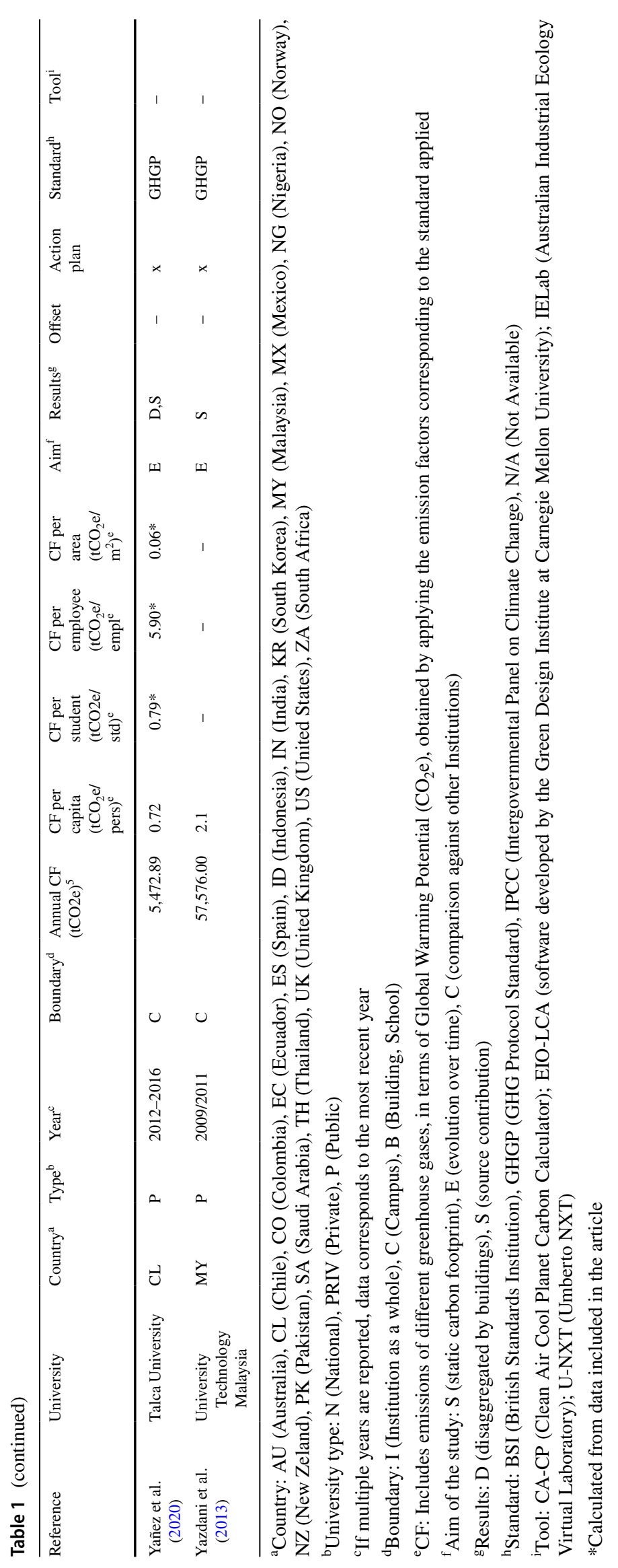


sions during a specific year (60\%). In addition, $46 \%$ of the studies compare their emissions with the $\mathrm{CF}$ of other universities and $80 \%$ of the studies analysed the effect of different measures aimed at reducing the $\mathrm{CF}$.

Table 2 reports the specific measures applied in the literature to reduce the $\mathrm{CF}$ of higher education institutions, classified by the scope they have an influence over. In addition to the measures reported in Table 2, there are other strategies that affect specific aspects of the institutions. At the buildings level, strategies, such as designs for low-energy buildings are proposed by Baboulet and Lenzen (2010) and Ozawa-Meida et al. (2013), infrastructure interventions are carried out using techniques and materials with a low carbon footprint by Varón-hoyos et al. (2021) or minimising the construction of new buildings by Jung et al. (2016) and Riedy and Daly (2010). Moreover, establishing a structured sustainability office/group responsible for monitoring, tracking and advocating for sustainability initiatives is proposed by Riedy and Daly (2010) and Bailey and LaPoint (2016), and integrating an environmental management system, is proposed by Rodríguez-Andara et al. (2020), since it will facilitate the calculation of emissions and their mitigation. In specific HEI, which use animals for teaching or research purposes, Butt (2012) proposed decreasing the number of grazing animals and increasing the per animal productivity or decreasing the amount of dung and urine added to the pasture through restricted grazing.

$23 \%$ of the studies analysed the improvement that would be obtained by applying these actions by accurately calculating the $\mathrm{tCO}_{2} \mathrm{e}$ saved or obtaining the specific percentage of reduction in emissions, while the rest of the studies reviewed only comment on the recommendations (see "Action CF improvement analysis (\%)" row in Table 2).

- Scope/Emission sources Traditionally, organisations have accounted for just Scope 1 (all direct emissions) and Scope 2 (indirect emissions from electricity purchased and used by the HEI) in their CF reports because they are the easiest and cheapest to assign and calculate. Quantifying Scope 3 (other indirect emissions) can be quite challenging for HEI, particularly for the largest and highly decentralised ones. Table 3 reports the emission sources for each scope considered in the studies reported in Table 1 and in Santovito and Abiko (2018), which offers recommendations on preparing the campus inventory.

Apart from the emission sources reported in Table 3, which are commonly considered in the general literature focussed on the calculation of $\mathrm{CF}$, other specific emission sources are considered in the studies reviewed, such as procurement of glassware, plasticware and capital woods (e.g. equipment and setups for scientific laboratories) (Sangwan et al. 2018), farm machinery (Ologun and Wara 2014) and trips for parents/friends visiting the campus (Ozawa-Meida et al. 2013).

Moreover, not all the source emissions are always considered in the same scope. Leakage of refrigerants is usually considered in Scope 1, although Sangwan et al. (2018) included them in Scope 3. On the contrary, other emission sources which are usually considered in Scope 3 are included in Scope 1 in some studies. For example, the purchase of fertilisers is included in Scope 1 by Bailey and LaPoint (2016) and Clabeaux et al. (2020), water supply by Budihardjo et al. (2020), Syafrudin et al. (2020) and Ullah et al. (2020) and wastewater treatment by Clabeaux et al. (2020) and Criollo et al. (2019). Finally, fuel used in power generators, which is usually considered in Scope 1, is included in Scope 2 by Güereca et al. (2013).

Figure 4 shows a graphic representation of the percentage distribution of the emission sources considered in the studies reviewed. As can be seen, not all emission sources have the same level of consideration. It can be observed that $100 \%$ of the studies consider scope 2, $86 \%$ consider scope 1 and $94 \%$ consider some source from scope 3. In scope 1, 72\% consider stationary consumption, $83 \%$ consider the vehicle fleet, while only $33 \%$ consider the leakage of refrigerants. In scope 2 , all the studies consider emissions from purchasing electricity and only Gu et al. (2019) considered the generation of electricity (renewable energy). Regarding scope 3, the five sources of emission that are considered the most are commuting $(75 \%)$, generation of waste $(75 \%)$, business trips $(56 \%)$ and the consumption/procurement of paper $(47 \%)$ and water $(36 \%)$.

Regarding the emission factors applied for each source of emissions, it can be observed that they are quite variable and depend mainly on the country, in which the institution under study is located. Current emission factors are available from many handbooks, government publications and the literature searches of appropriate research papers and journals. Some studies do not report the reference source of the emission factors (7\%) and none of them report the specific list of emission factors that are applied. Some studies used emission factors provided by official government sources, for example, Butt (2012) from New Zealand, Criollo et al. (2019) from UK, Mendoza-Flores et al. (2019) from Mexico, Ridhosari and Rahman (2020) from Indonesia or RodríguezAndara et al. (2020) from Spain. Most of them are based on relevant sources, such as IPCC, DEFRA or EPA.

- Data source Data related to the consumption of energy, fuel, water, etc. are usually obtained directly from primary sources (field data obtained directly from the institution under analysis) in the studies reviewed, that is, through bills, counters, etc. and for the same base year, 
Table 2 Specific actions to reduce the CF

\begin{tabular}{|c|c|c|c|}
\hline Scope & Measure & Reference where measures are applied/proposed & \\
\hline \multirow[t]{8}{*}{ Scope 1} & \multirow{7}{*}{$\begin{array}{l}\text { Fixed } \\
\text { con- } \\
\text { sump- } \\
\text { tion }\end{array}$} & Accurate maintenance of boilers/heating system & Rodríguez-Andara et al. (2020), Yañez et al. (2020) \\
\hline & & Using a condenser boiler to increase performance & Rodríguez-Andara et al. (2020) \\
\hline & & Replacement of fossil fuels by renewable energy & $\begin{array}{l}\text { Klein-Banai et al. (2010), Riedy and Daly (2010), Gu et al. (2019), Mendoza- } \\
\text { Flores et al. (2019), Rodríguez-Andara et al. (2020), Yañez et al. (2020) }\end{array}$ \\
\hline & & $\begin{array}{l}\text { Insulating certain building compartments from air condi- } \\
\text { tioning }\end{array}$ & Rodríguez-Andara et al. (2020) \\
\hline & & Installing thermostatic valves on radiators & Rodríguez-Andara et al. (2020) \\
\hline & & Applying window film to all glass-openings on buildings & Iskandar et al. (2020) \\
\hline & & Improving the insulation system & Rodríguez-Andara et al. (2020) \\
\hline & Fleet & $\begin{array}{l}\text { Replacing petrol-driven vehicles with electric or natural gas } \\
\text { vehicles }\end{array}$ & Ozawa-Meida et al. (2013), Mendoza-Flores et al. (2019) \\
\hline \multirow[t]{17}{*}{ Scope 2} & \multirow{14}{*}{$\begin{array}{l}\text { Electric- } \\
\text { ity } \\
\text { con- } \\
\text { sump- } \\
\text { tion }\end{array}$} & Replacing lamps with more efficient types, such as LEDs & $\begin{array}{l}\text { Klein-Banai et al. (2010), Güereca et al. (2013), Vásquez et al. (2015), } \\
\text { Laingoen et al. (2016), Gu et al. (2019), Iskandar et al. (2020), Yañez et al. } \\
\text { (2020) }\end{array}$ \\
\hline & & $\begin{array}{l}\text { Modifying the electrical circuits to switch on only the } \\
\text { required lamps }\end{array}$ & Riedy and Daly (2010), Güereca et al. (2013) \\
\hline & & Installing a presence detection control system or sensors & $\begin{array}{l}\text { Gu et al. (2019), Ridhosari and Rahman (2020), Rodríguez-Andara et al. } \\
\text { (2020), Ullah et al. (2020), Yañez et al. (2020) }\end{array}$ \\
\hline & & Adapting the boilers to make them highly efficient & $\begin{array}{l}\text { Baboulet and Lenzen (2010), Riedy and Daly (2010), Gómez et al. (2016), } \\
\text { Rodríguez-Andara et al. (2020), Yañez et al. (2020) }\end{array}$ \\
\hline & & Installing more efficient air conditioning equipment & $\begin{array}{l}\text { Riedy and Daly (2010), Laingoen et al. (2016), Criollo et al. (2019), } \\
\text { Rodríguez-Andara et al. (2020) }\end{array}$ \\
\hline & & $\begin{array}{l}\text { Replacing electrical appliances with other more efficient } \\
\text { ones }\end{array}$ & Laingoen et al. (2016), Rodríguez-Andara et al. (2020) \\
\hline & & $\begin{array}{l}\text { Installing a general energy management system (allows } \\
\text { changes to heating, air conditioning and lighting) }\end{array}$ & $\begin{array}{l}\text { Moerschbaecher and Day (2010), Larsen et al. (2013), Ozawa-Meida et al. } \\
\text { (2013), Yazdani et al. (2013), Rodríguez-Andara et al. (2020), Syafrudin } \\
\text { et al. (2020), Ullah et al. (2020), Yañez et al. (2020) }\end{array}$ \\
\hline & & $\begin{array}{l}\text { Purchasing renewable energy. Renewable energy certificates } \\
\text { (RECs) }\end{array}$ & $\begin{array}{l}\text { Baboulet and Lenzen (2010), Moerschbaecher and Day (2010), Riedy and } \\
\text { Daly (2010), Bailey and LaPoint (2016), Criollo et al. (2019), Clabeaux } \\
\text { et al. (2020) }\end{array}$ \\
\hline & & $\begin{array}{l}\text { Use renewable energy sources, such as geothermal heating } \\
\text { and cooling systems, solar photovoltaic systems or wind } \\
\text { turbines on the roof }\end{array}$ & $\begin{array}{l}\text { Riedy and Daly (2010), Klein-Banai et al. (2010), Moerschbaecher and Day } \\
\text { (2010), Ologun and Wara (2014), Almufadi and Irfan (2016), Jung et al. } \\
\text { (2016), Criollo et al. (2019), Gu et al. (2019), Clabeaux et al. (2020), } \\
\text { Ridhosari and Rahman (2020), Rodríguez-Andara et al. (2020), Ullah et al. } \\
\text { (2020), Iskandar et al. (2020), Varón-hoyos et al. (2021), Naderipour et al. } \\
\text { (2021) }\end{array}$ \\
\hline & & Cogeneration & Moerschbaecher and Day (2010) \\
\hline & & Reducing opening hours & Larsen et al. (2013) \\
\hline & & $\begin{array}{l}\text { Consumer action (turning off lights in unoccupied offices, } \\
\text { avoiding standby modes of office computers and machin- } \\
\text { ery) }\end{array}$ & $\begin{array}{l}\text { Riedy and Daly (2010), Güereca et al. (2013), Larsen et al. (2013), Laingoen } \\
\text { et al. (2016), Rodríguez-Andara et al. (2020), Ullah et al. (2020) }\end{array}$ \\
\hline & & $\begin{array}{l}\text { Community activities (dining in the canteen, studying in the } \\
\text { library) }\end{array}$ & Yañez et al. (2020) \\
\hline & & $\begin{array}{l}\text { Sharing expensive and embodied energy intensive equip- } \\
\text { ment }\end{array}$ & Stephan et al. (2020) \\
\hline & \multirow{3}{*}{$\begin{array}{l}\text { Electric- } \\
\text { ity/ } \\
\text { trans- } \\
\text { port }\end{array}$} & Video-conference & $\begin{array}{l}\text { Moerschbaecher and Day (2010), Larsen et al. (2013), Yazdani et al. (2013), } \\
\text { Mendoza-Flores et al. (2019), Varón-hoyos et al. (2021) }\end{array}$ \\
\hline & & Transition to a four-day workweek & Moerschbaecher and Day (2010) \\
\hline & & Working from home & $\begin{array}{l}\text { Güereca et al. (2013), Robinson et al. (2018), Criollo et al. (2019), Jarillo } \\
\text { et al. (2019), Varón-hoyos et al. (2021) }\end{array}$ \\
\hline
\end{tabular}


Table 2 (continued)

\begin{tabular}{|c|c|c|c|}
\hline \multirow{2}{*}{$\begin{array}{l}\text { Scope } \\
\text { Scope } 3\end{array}$} & \multirow{2}{*}{$\begin{array}{c}\text { Measure } \\
\begin{array}{c}\text { Trans- } \\
\text { port }\end{array}\end{array}$} & \multicolumn{2}{|l|}{ Reference where measures are applied/proposed } \\
\hline & & $\begin{array}{l}\text { Campaigns to encourage students and staff to replace their } \\
\text { own vehicles (automobile and motorcycle) by bicycles or } \\
\text { public transport (bus, metro or train) }\end{array}$ & $\begin{array}{l}\text { Moerschbaecher and Day (2010), Butt (2012), Güereca et al. (2013), Ozawa- } \\
\text { Meida et al. (2013), Vásquez et al. (2015), Gómez et al. (2016), Jung et al. } \\
\text { (2016), Criollo et al. (2019), Mendoza-Flores et al. (2019), Rodríguez- } \\
\text { Andara et al. (2020), Ullah et al. (2020), Yañez et al. (2020), Iskandar et al. } \\
\text { (2020), Varón-hoyos et al. (2021), Naderipour et al. (2021) }\end{array}$ \\
\hline & & Transportation subsidy programme & Varón-hoyos et al. (2021) \\
\hline & & Building cycle lanes & Criollo et al. (2019) \\
\hline & & Creating a programme for lending bikes & Criollo et al. (2019) \\
\hline & & Promote the use of electric scooters within the university & Naderipour et al. (2021) \\
\hline & & Increasing the number of parking spaces for bicycles & Gómez et al. (2016), Naderipour et al. (2021) \\
\hline & & Installing charging facilities for electric vehicles & Gómez et al. (2016), Varón-hoyos et al. (2021) \\
\hline & & Implementing the policy of charging for parking & Iskandar et al. (2020) \\
\hline & & Regulating the entry to campus parking & Varón-hoyos et al. (2021) \\
\hline & & $\begin{array}{l}\text { Users need to take a survey in order to receive a parking } \\
\text { permit }\end{array}$ & Bailey and LaPoint (2016) \\
\hline & & Promoting carpooling (car sharing) & $\begin{array}{l}\text { Güereca et al. (2013), Ozawa-Meida et al. (2013), Criollo et al. (2019), Ullah } \\
\text { et al. (2020), Yañez et al. (2020) }\end{array}$ \\
\hline & & $\begin{array}{l}\text { Providing university buses or sign an agreement with the } \\
\text { service providers }\end{array}$ & $\begin{array}{l}\text { Ologun and Wara (2014), Gómez et al. (2016), Ridhosari and Rahman (2020), } \\
\text { Syafrudin et al. (2020), Ullah et al. (2020); Naderipour et al. (2021) }\end{array}$ \\
\hline & & Providing dormitories to reduce transportation needs & Ridhosari and Rahman (2020), Yañez et al. (2020) \\
\hline & & Avoiding the use of air travel for short trips & Mendoza-Flores et al. (2019) \\
\hline & Water & $\begin{array}{l}\text { Building facilities for processing and storing rainwater and } \\
\text { grey-water }\end{array}$ & Iskandar et al. (2020) \\
\hline & & Promoting the reduction of water consumption & Varón-hoyos et al. (2021) \\
\hline & & Renewing the water pipeline system & Ullah et al. (2020) \\
\hline & Waste & Reuse or recycling of waste before sending it to landfill & $\begin{array}{l}\text { Larsen et al. (2013), Ozawa-Meida et al. (2013), Gu et al. (2019), Mendoza- } \\
\text { Flores et al. (2019), Iskandar et al. (2020), Ridhosari and Rahman (2020), } \\
\text { Stephan et al. (2020) Ullah et al. (2020) }\end{array}$ \\
\hline & & Sending the waste to a waste bank & Iskandar et al. (2020) \\
\hline & & Incentives for waste prevention & Ullah et al. (2020) \\
\hline & $\begin{array}{l}\text { Procure- } \\
\text { ment }\end{array}$ & $\begin{array}{l}\text { Procurement policies based on environmental criteria (green } \\
\text { procurement) }\end{array}$ & $\begin{array}{l}\text { Baboulet and Lenzen (2010), Thurston and Eckelman (2011), Larsen et al. } \\
\text { (2013), Gómez et al. (2016), Stephan et al. (2020), Ullah et al. (2020), } \\
\text { Naderipour et al. (2021), Varón-hoyos et al. (2021) }\end{array}$ \\
\hline & & Purchasing recycled paper & Baboulet and Lenzen (2010) \\
\hline & & Promoting digital reading & Gómez et al. (2016) \\
\hline & & Introducing an ecotax & Gómez et al. (2016) \\
\hline & & Reducing solvents used in the laboratory & Mendoza-Flores et al. (2019) \\
\hline & & Switching to/encouraging a more vegetable-based diet & $\begin{array}{l}\text { Baboulet and Lenzen (2010), Gómez et al. (2016), Gu et al. (2019), Mendoza- } \\
\text { Flores et al. (2019) }\end{array}$ \\
\hline $\begin{array}{l}\text { Offset } \\
\text { emis- } \\
\text { sions }\end{array}$ & Reforesta & ion projects & $\begin{array}{l}\text { Riedy and Daly (2010), Ologun and Wara (2014), Almufadi and Irfan (2016), } \\
\text { Bailey and LaPoint (2016), Clabeaux et al. (2020), Iskandar et al. (2020), } \\
\text { Rodríguez-Andara et al. (2020), Syafrudin et al. (2020), Yañez et al. (2020) }\end{array}$ \\
\hline Action $\mathrm{C}$ & improvem & ent analysis $(\%)$ & $\begin{array}{l}\text { Moerschbaecher and Day (2010), Güereca et al. (2013), Vásquez et al. (2015), } \\
\text { Laingoen et al. (2016), Rodríguez-Andara et al. (2020), Stephan et al. } \\
\text { (2020), Yañez et al. (2020), Varón-hoyos et al. (2021) }\end{array}$ \\
\hline
\end{tabular}


Table 3 Emission sources considered in the literature

\begin{tabular}{|c|c|c|c|c|c|c|c|c|c|c|c|c|c|c|c|c|c|c|}
\hline \multirow[t]{2}{*}{ Reference } & \multicolumn{3}{|c|}{ Scope 1} & \multicolumn{2}{|c|}{ Scope 2} & \multicolumn{13}{|c|}{ Scope 3} \\
\hline & $\mathrm{S}$ & $\mathrm{R}$ & $\mathrm{V}$ & $\mathrm{P}$ & G & Con & ump & $\operatorname{lon}^{\mathrm{c}}$ & & Tral & sport $^{\mathrm{c}}$ & & & & Waste & $\mathrm{WT}^{\mathrm{e}}$ & Consf & Elegg \\
\hline Almufadi and Irfan (2016) & & & $\mathrm{x}$ & $\mathrm{x}$ & & & & & & & & & $\mathrm{C}$ & & & & & \\
\hline Alvarez et al. (2014) & $\mathrm{x}$ & & $\mathrm{x}$ & $\mathrm{x}$ & & W & $\mathrm{P}$ & & $\mathrm{LC}$ & $\mathrm{EE}$ & & BT & & $\mathrm{S}$ & $\mathrm{x}$ & & & $\mathrm{x}$ \\
\hline Baboulet and Lenzen (2010) & $\mathrm{x}$ & $\mathrm{x}$ & & $\mathrm{x}$ & & & $\mathrm{P}$ & $\mathrm{F}$ & $\mathrm{LC}$ & $\mathrm{EE}$ & & BT & & & & & & \\
\hline Bailey and LaPoint (2016) & $\mathrm{x}$ & $\mathrm{x}$ & $\mathrm{x}$ & $\mathrm{x}$ & & & $\mathrm{P}$ & & & & & BT & $\mathrm{C}$ & & $\mathrm{x}$ & $\mathrm{x}$ & & $\mathrm{x}$ \\
\hline Budihardjo et al. (2020) & & & & $\mathrm{x}$ & & $\mathrm{W}$ & & & & & & & & & $\mathrm{x}$ & $\mathrm{x}$ & & \\
\hline Butt (2012) & $\mathrm{x}$ & & $\mathrm{x}$ & $\mathrm{x}$ & & & & & & & & BT & $\mathrm{C}$ & & $\mathrm{x}$ & $\mathrm{x}$ & & \\
\hline Clabeaux et al. (2020) & $\mathrm{x}$ & $\mathrm{x}$ & $\mathrm{x}$ & $\mathrm{x}$ & & & $\mathrm{P}$ & & & & $\mathrm{FE}$ & BT & $\mathrm{C}$ & & $\mathrm{x}$ & $\mathrm{x}$ & & $\mathrm{x}$ \\
\hline Criollo et al. (2019) & $\mathrm{x}$ & $\mathrm{x}$ & $\mathrm{x}$ & $\mathrm{x}$ & & & & & & & & & & & & $\mathrm{x}$ & & \\
\hline Gómez et al. (2016) & $\mathrm{x}$ & & $\mathrm{x}$ & $\mathrm{x}$ & & W & $\mathrm{P}$ & $\mathrm{F}$ & $\mathrm{LC}$ & $\mathrm{EE}$ & FE & BT & & & $\mathrm{x}$ & & $\mathrm{x}$ & $\mathrm{x}$ \\
\hline Gu et al. (2019) & $\mathrm{x}$ & & $\mathrm{x}$ & $\mathrm{x}$ & $\mathrm{X}$ & W & & $\mathrm{F}$ & & & & & & & $\mathrm{x}$ & $\mathrm{x}$ & & \\
\hline Güereca et al. (2013) & $\mathrm{x}$ & & $\mathrm{x}$ & $\mathrm{x}$ & & & $\mathrm{P}$ & & & & & BT & $\mathrm{C}$ & $\mathrm{S}$ & $\mathrm{x}$ & & & \\
\hline Iskandar et al. (2020) & & & $\mathrm{x}$ & $\mathrm{x}$ & & $\mathrm{W}$ & $\mathrm{P}$ & $\mathrm{F}$ & & & & BT & $\mathrm{C}$ & & $\mathrm{x}$ & & & \\
\hline Jung et al. (2016) & $\mathrm{x}$ & & $\mathrm{x}$ & $\mathrm{x}$ & & $\mathrm{W}$ & & & & & & & $\mathrm{C}$ & & $\mathrm{x}$ & $\mathrm{x}$ & & \\
\hline Kandananond (2017) & & & $\mathrm{x}$ & $\mathrm{x}$ & & & & & & & & & & & & & & \\
\hline Klein-Banai et al. (2010) & $\mathrm{x}$ & & $\mathrm{x}$ & $\mathrm{x}$ & & & & & & & & & $\mathrm{C}$ & & $\mathrm{x}$ & & & $\mathrm{x}$ \\
\hline Laingoen et al. (2016) & & & & $\mathrm{x}$ & & & & & & & & & & & & & & \\
\hline Larsen et al. (2013) & $\mathrm{x}$ & $\mathrm{x}$ & $\mathrm{x}$ & $\mathrm{X}$ & & & $\mathrm{P}$ & $\mathrm{F}$ & $\mathrm{LC}$ & $\mathrm{EE}$ & & BT & $\mathrm{C}$ & & $\mathrm{x}$ & & $\mathrm{x}$ & \\
\hline Letete et al. (2011) & $\mathrm{x}$ & & $\mathrm{x}$ & $\mathrm{x}$ & & & $\mathrm{P}$ & & & & & BT & $\mathrm{C}$ & & $\mathrm{x}$ & $\mathrm{x}$ & & $\mathrm{x}$ \\
\hline Mendoza-Flores et al. (2019) & $\mathrm{x}$ & $\mathrm{x}$ & $\mathrm{x}$ & $\mathrm{x}$ & & W & $\mathrm{P}$ & $\mathrm{F}$ & $\mathrm{LC}$ & & & BT & $\mathrm{C}$ & & $\mathrm{x}$ & $\mathrm{x}$ & & \\
\hline Moerschbaecher and Day (2010) & $\mathrm{x}$ & $\mathrm{x}$ & $\mathrm{x}$ & $\mathrm{x}$ & & & & & & & & BT & $\mathrm{C}$ & & $\mathrm{x}$ & $\mathrm{x}$ & & $\mathrm{x}$ \\
\hline Naderipour et al. (2021) & & & $\mathrm{x}$ & $\mathrm{x}$ & & $\mathrm{W}$ & $\mathrm{P}$ & & & & & & $\mathrm{C}$ & & $\mathrm{x}$ & & & \\
\hline Ologun and Wara (2014) & $\mathrm{x}$ & & $\mathrm{x}$ & $\mathrm{x}$ & & & & & & & & & $\mathrm{C}$ & & & & & \\
\hline Ozawa-Meida et al. (2013) & $\mathrm{x}$ & & $\mathrm{x}$ & $\mathrm{x}$ & & $\mathrm{W}$ & $\mathrm{P}$ & $\mathrm{F}$ & $\mathrm{LC}$ & $\mathrm{EE}$ & & BT & $\mathrm{C}$ & & $\mathrm{x}$ & & $\mathrm{x}$ & $\mathrm{x}$ \\
\hline Quintero-Núñez et al. (2015) & & & & $\mathrm{x}$ & & $\mathrm{W}$ & $\mathrm{P}$ & & & & & & $\mathrm{C}$ & & & & $\mathrm{x}$ & \\
\hline Ridhosari and Rahman (2020) & & & & $\mathrm{x}$ & & & & & & & & & $\mathrm{C}$ & & $\mathrm{x}$ & & & \\
\hline Rodríguez-Andara et al. (2020) & $\mathrm{x}$ & $\mathrm{x}$ & $\mathrm{x}$ & $\mathrm{x}$ & & $\mathrm{W}$ & $\mathrm{P}$ & & & & & & $\mathrm{C}$ & & $\mathrm{x}$ & & $\mathrm{x}$ & \\
\hline Sangwan et al. (2018) & $\mathrm{x}$ & & $\mathrm{x}$ & $\mathrm{x}$ & & W & $\mathrm{P}$ & $\mathrm{F}$ & $\mathrm{LC}$ & $\mathrm{EE}$ & & BT & $\mathrm{C}$ & & $\mathrm{x}$ & $\mathrm{x}$ & & \\
\hline Santovito and Abiko (2018)* & $\mathrm{x}$ & $\mathrm{x}$ & $\mathrm{x}$ & $\mathrm{x}$ & & & & & & & FE & BT & $\mathrm{C}$ & & $\mathrm{x}$ & $\mathrm{x}$ & & \\
\hline Stephan et al. (2020) & $\mathrm{x}$ & & & $\mathrm{x}$ & & $\mathrm{W}$ & $\mathrm{P}$ & $\mathrm{F}$ & $\mathrm{LC}$ & $\mathrm{EE}$ & & & $\mathrm{C}$ & & $\mathrm{x}$ & & & \\
\hline Syafrudin et al. (2020) & & & & $\mathrm{x}$ & & W & & & & & & & $\mathrm{C}$ & & $\mathrm{x}$ & $\mathrm{x}$ & & \\
\hline Thurston and Eckelman (2011) & $\mathrm{x}$ & & $\mathrm{x}$ & $\mathrm{x}$ & & & & & & & & BT & $\mathrm{C}$ & & & & & \\
\hline Townsend and Barrett (2015) & $\mathrm{x}$ & & $\mathrm{x}$ & $\mathrm{x}$ & & & $\mathrm{P}$ & $\mathrm{F}$ & $\mathrm{LC}$ & $\mathrm{EE}$ & & BT & & & $\mathrm{x}$ & & $\mathrm{x}$ & \\
\hline Ullah et al. (2020) & $\mathrm{x}$ & & $\mathrm{x}$ & $\mathrm{x}$ & & $\mathrm{W}$ & & $\mathrm{F}$ & $\mathrm{LC}$ & $\mathrm{EE}$ & FE & & $\mathrm{C}$ & & $\mathrm{X}$ & & & \\
\hline Varón-hoyos et al. (2021) & $\mathrm{x}$ & $\mathrm{x}$ & $\mathrm{x}$ & $\mathrm{x}$ & & W & $\mathrm{P}$ & & & & & BT & $\mathrm{C}$ & & $\mathrm{x}$ & $\mathrm{x}$ & $\mathrm{x}$ & \\
\hline Vásquez et al. (2015) & $\mathrm{x}$ & $\mathrm{x}$ & $\mathrm{x}$ & $X$ & & & & & & & & BT & $\mathrm{C}$ & $\mathrm{S}$ & & & & \\
\hline Yañez et al. (2020) & $\mathrm{x}$ & $\mathrm{x}$ & $\mathrm{x}$ & $\mathrm{x}$ & & & $\mathrm{P}$ & & & & & BT & $\mathrm{C}$ & & $\mathrm{x}$ & & & \\
\hline Yazdani et al. (2013) & & & $\mathrm{x}$ & $\mathrm{x}$ & & & & & & & & & $\mathrm{C}$ & & $\mathrm{x}$ & & & \\
\hline
\end{tabular}

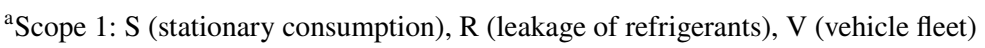

${ }^{\mathrm{b}}$ Scope 2: P (purchased), G (generated)

${ }^{\mathrm{c}}$ Consumption: W (water), P (paper), F (food), LC (laboratory chemicals), EE (electronic equipment), FE (Fertiliser)

${ }^{\mathrm{d}}$ Transport: BT (business travel), C (commuting), S (supplies)

${ }^{\mathrm{e}} \mathrm{WT}$ : Wastewater

${ }^{\mathrm{f}}$ Cons: Construction

${ }^{g}$ Elec: Electricity (transportation and distribution losses from purchased electricity)

*Article with recommendations for preparing the GHG inventory for university campuses 
Fig. 4 Emission sources considered in the articles analyse

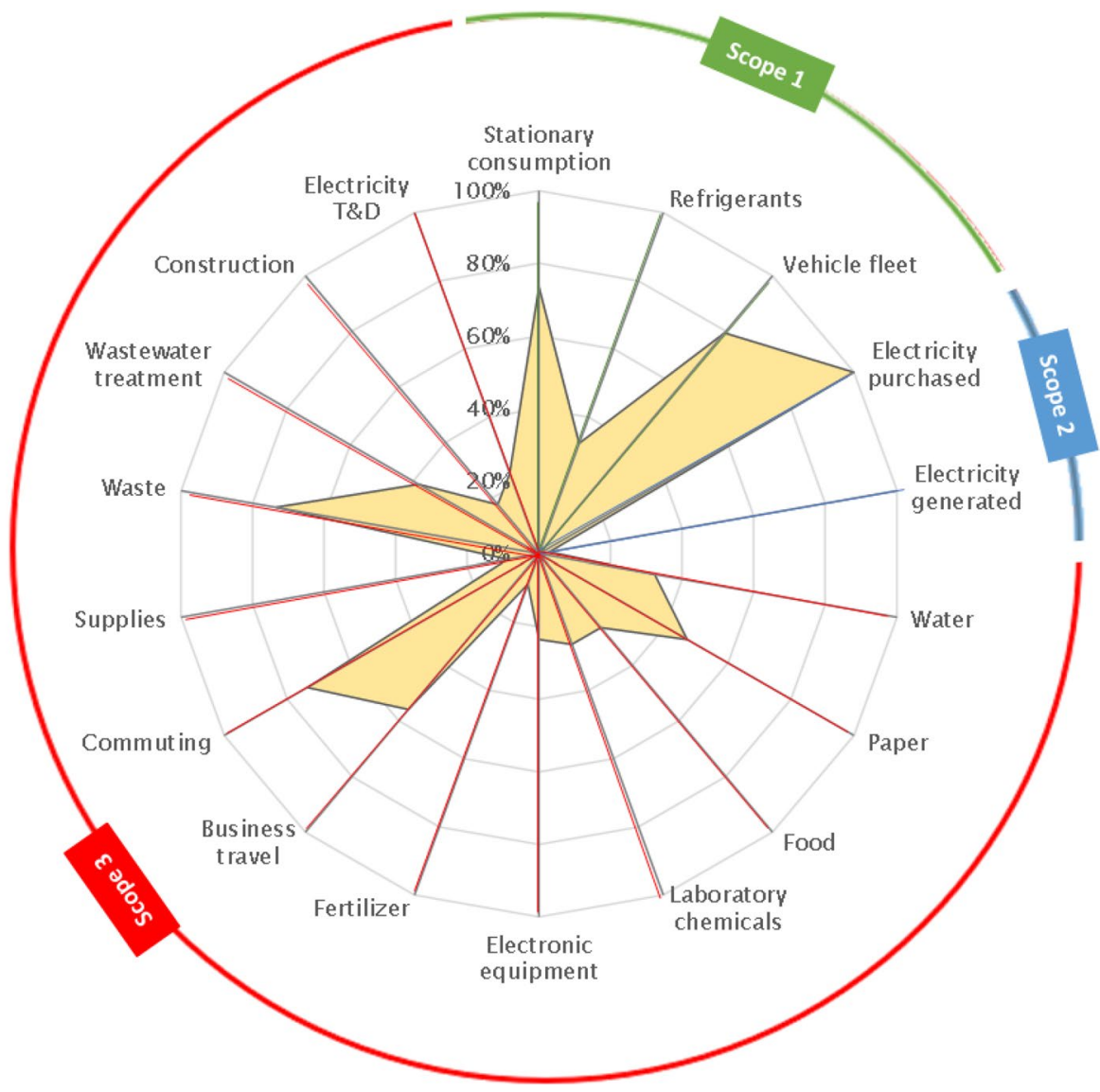

which allows reliable and accurate results to be obtained. For commuting and paper consumption, however, data are commonly obtained through a survey carried out with students and/or employers, which involves a certain degree of uncertainty since it depends on the veracity of the answers and the respondents' level of involvement. Nevertheless, due to limited data availability, some studies need to make assumptions, such as Letete et al. (2011) that considers the consumption of LPG, acetylene and transport in November 2007 as the average consumption from January to October and the same electricity consumption for the previous year; other studies extrapolate daily or monthly data to annual data (Quintero-Núñez et al. (2015) calculates an average daily electricity consumption for winter and summer and extrapolates it to the total number of working days; Almufadi and Irfan (2016) extrapolate daily transport data to annual data and Iskandar et al. (2020b) calculate monthly carbon footprint), Güereca et al. (2013) extrapolates data from one building to the rest of the institution analysed and Ozawa-Meida et al. (2013) extrapolates commuting information extracted from surveys to the whole university. Other studies also used surveys to estimate data for the consumption of fuel in generators (Ologun and Wara, 2014), for electricity consumption by lighting/equipment
(Güereca et al., 2013) and for LPG consumed in residential colony (Ullah et al. 2020).

- Tool for CF calculation Most of the studies reviewed (83\%) do not use any commercial/free CF calculation tools; instead, the calculations are performed with their own means. The remaining studies applied different tools: Clean Air Cool Planet Carbon Calculator (CA-CP 2020) was used by Bailey and LaPoint (2016), KleinBanai et al. (2010) and Moerschbaecher and Day (2010), Economic Input-Output Life Cycle Assessment on-line tool (EIO-LCA 2020) was employed by Thurston and Eckelman (2011), IELab (2020) was implemented by Stephan et al. (2020), Umberto Software (Umberto 2020) was the tool used by Sangwan et al. (2018) and SimaPro (Pre Consultants 2019) was employed by (Ullah et al. 2020).

\section{Comparison of results}

The annual CF is reported in all the studies reviewed, although they are not comparable due to the different sizes of the institutions/campuses/schools/faculties analysed. In order to create a meaningful study despite these differences and to obtain a good basis for comparing the $\mathrm{CF}$, a normalisation based on different criteria (student, employee, 
Table 4 Normalised $\mathrm{CF}$ according to different units

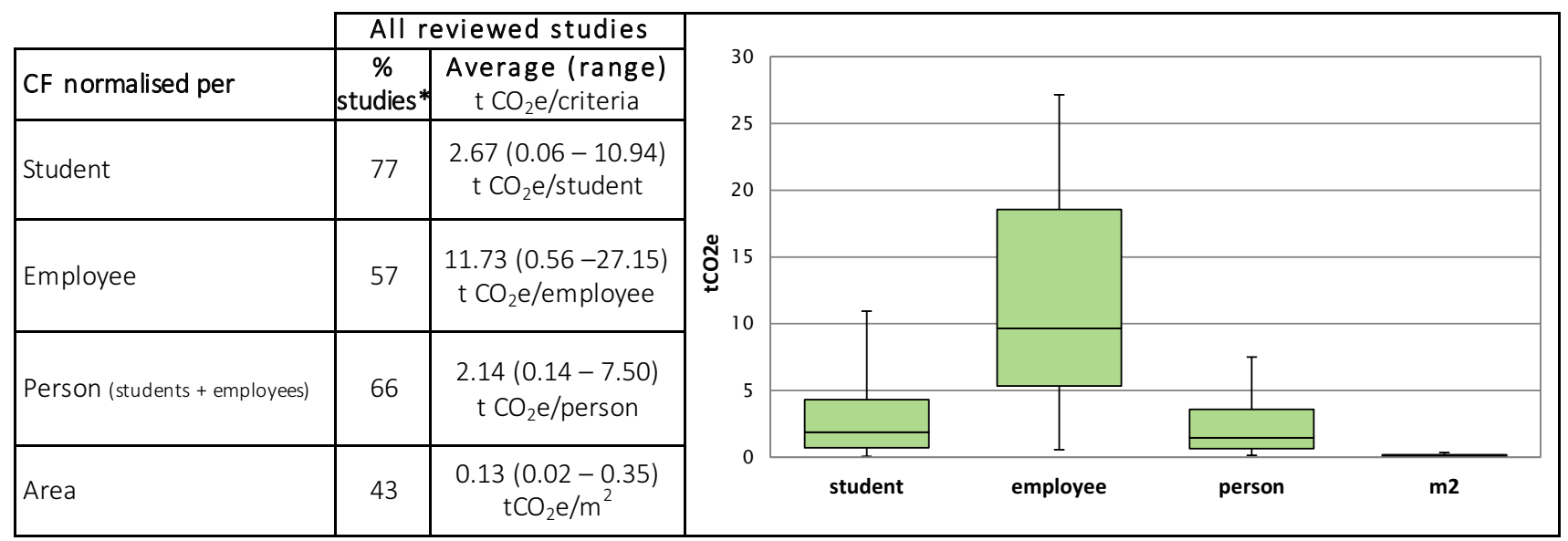

*Percentage of studies reviewed that include data for calculating the normalised CF according to each criterion

capita and area) is applied, as reported in Table 4. In addition, comparing this rate with the location of the HEI also reveals differences: 5.25/2.30/2.25/1.77/0.67 t $\mathrm{CO}_{2} \mathrm{e} /$ student on average for North America, Africa, Europe, Asia and South America, respectively. As a general result, it can be observed that the range of variation is very wide, regardless of the standardisation criteria applied. Moreover, other studies, especially those focussed on assessing the CF of university purchases ( $\mathrm{t} \mathrm{CO}_{2} \mathrm{e} / €$ purchased), obtain less representative results due to the variety of potential purchases: $0.38 \mathrm{kgCO}_{2} \mathrm{e} / €$ (Larsen et al. 2013), $0.34 \mathrm{kgCO}_{2} \mathrm{e} / €($ OzawaMeida et al. 2013) or $2.81 \mathrm{kgCO}_{2} \mathrm{e} / €$ (Alvarez et al. 2014). This fact clearly denotes a lack of homogeneous criteria when conducting the study.

- Disaggregation of results All the studies calculate the CF for the defined boundary. However, $29 \%$ of the studies disaggregate the results per building of the institution/ campus/school and $88 \%$ disaggregate them by the source causing the GHG emissions.

- Offset emissions Only 14\% of the studies have calculated their compensation potential, obtaining an emission offset ranging from $0.09 \%$ to $18 \%$. However, many studies (26\%) recognise the importance of incorporating university reforestation. For this reason, they include offset emissions as one of their recommendations for reducing the Carbon Footprint (see "Offset emissions" row in Table 3).

\section{Discussion}

Clear differences have been identified when the normalised CF from different HEI are compared. The main reason for this is the lack of a single international standardisation method for calculating the CF for organisations and specifically for educational institutions, which present certain peculiarities when compared to organisations in other areas. This study has highlighted the main aspects that require international consensus in order to obtain comparable results.

The first aspect is related to the need to establish a common time metric and functional unit. As activities in HEI do not remain constant over time-including face-to-face teaching, exams, holidays, etc. (Bailey and LaPoint 2016)it is desirable not to extrapolate data from a specific period. It seems to be more advisable to consider the fiscal year (instead of the academic year) as a temporal basis for calculating the $\mathrm{CF}$ in educational institutions, since emission factors are revised and published annually. Hence, it is recommendable to implement mechanisms for keeping historical records.

Furthermore, consensus is needed as regards the reference unit applied to normalise the $\mathrm{CF}$, in order to be able to make comparisons amongst HEI. It would be recommendable to use $\mathrm{kg} \mathrm{CO}_{2} \mathrm{e} /$ student, since it is directly related to the function of the HEI. It is also in agreement with the definition of the functional unit in the LCA methodology (ISO 14040 2006).

To analyse the values of the CF in greater depth, the evolution of the $\mathrm{CF} /$ student over time is represented in Fig. 5. It can be seen that, in spite of the differences amongst the studies reviewed, a trend is sensed towards the reduction in the CF over time, probably due to the increasing environmental awareness of HEI.

As set out in the previous section, one of the main reasons for the differences observed amongst the normalised $\mathrm{CF}$ in the studies reviewed is the scope and the emission sources considered in each of them. Figure 6 shows the normalised $\mathrm{CF}$ for those studies that allow its calculation ( $78 \%$ of the studies reviewed). The bar that represents the value of the $\mathrm{CF} / \mathrm{student}$ for each study is shown in colour, 
which depends on the contribution of each scope to the CF: green for scope 1, blue for scope 2 and yellow/red/purple for scope 3 .

It should also be noted that the CF from each study are not directly comparable, since they do not include the same emission sources, as Figs. 4 and 6 show. Some of them only consider a single emission source, while other studies use

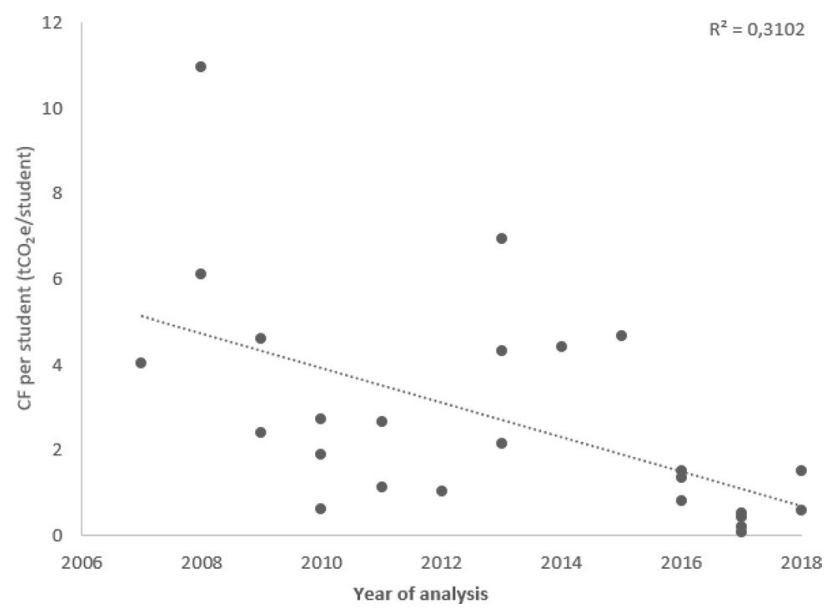

Fig. 5 Normalised carbon footprint: temporal evolution of CF per student almost all those reported in Table 3. However, the contribution of each emission source is quite variable depending on the value of its corresponding emission factor. Figure 7 represents the average contribution that each source emission has on the CF of studies reviewed.

As can be seen in Fig. 7, the major contribution to the $\mathrm{CF}$ in HEI comes from electricity consumption in buildings (scope 2), followed by daily commuting to and from the campus (scope 3), as also remarked by Bailey and LaPoint (2016) for universities located in U.S., Butt (2012) in New Zealand, Güereca et al. (2013) in México and Jung et al. (2016) in Korea. Scope 3 emissions represent the main source of CF in most of the HEI where they were counted. Scope 3 accounted for around $79 \%$ of the total CF of Montfort University (Ozawa-Meida et al. 2013), around 68\% for the Curicó Campus of Talca University (Vásquez et al. 2015) and up to $80 \%$ in Castilla-La Mancha University (Gómez et al. 2016).

This discussion stresses the need for a standardised framework for calculating the CF of organisations and specifically for HEI. In addition, it is also important to remark the need to include scope 3 in the near future (it is usually optional), since it represents a large percentage of emissions and is a good source of action to reduce emissions.

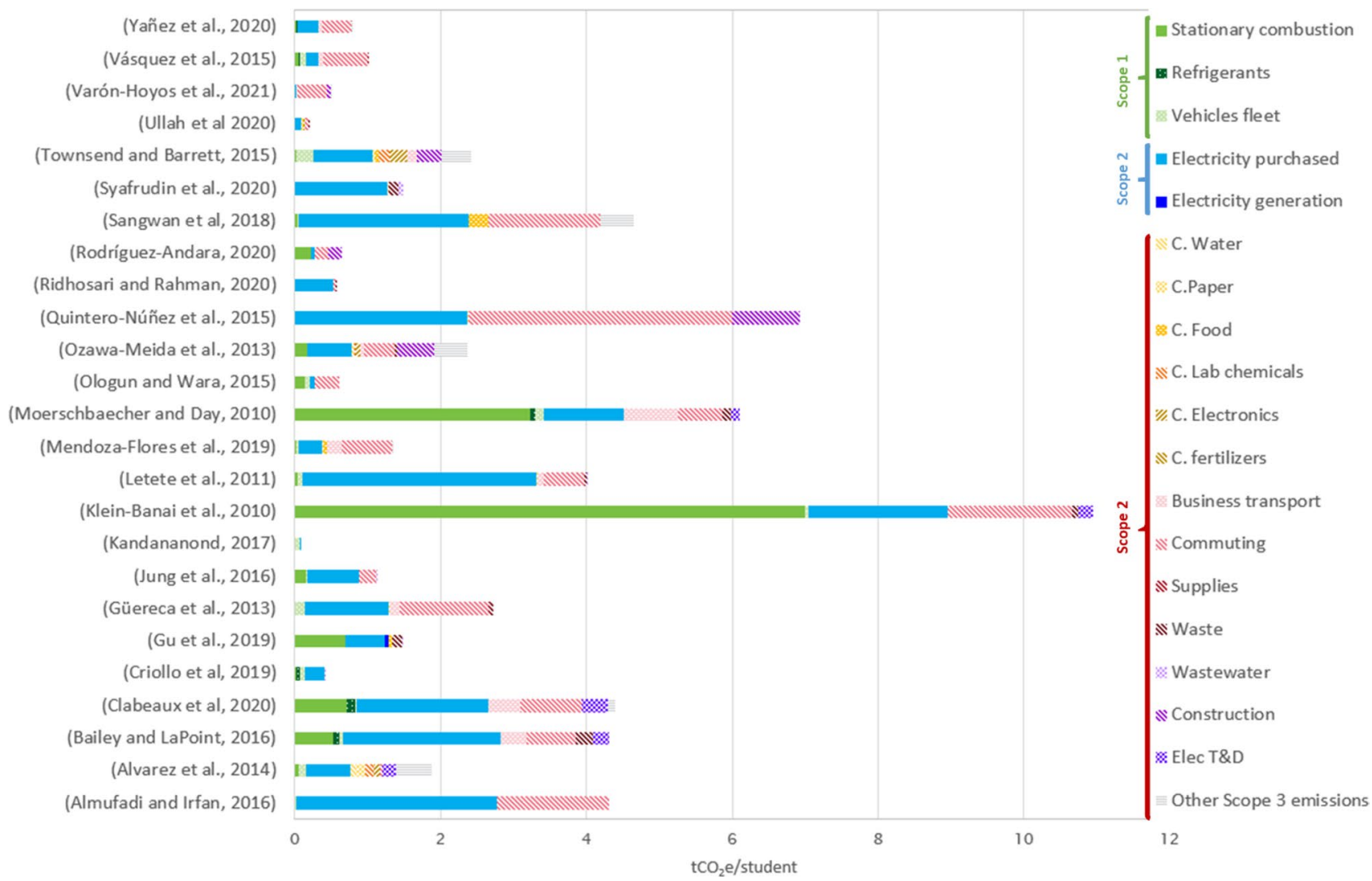

Fig. 6 Emission sources 


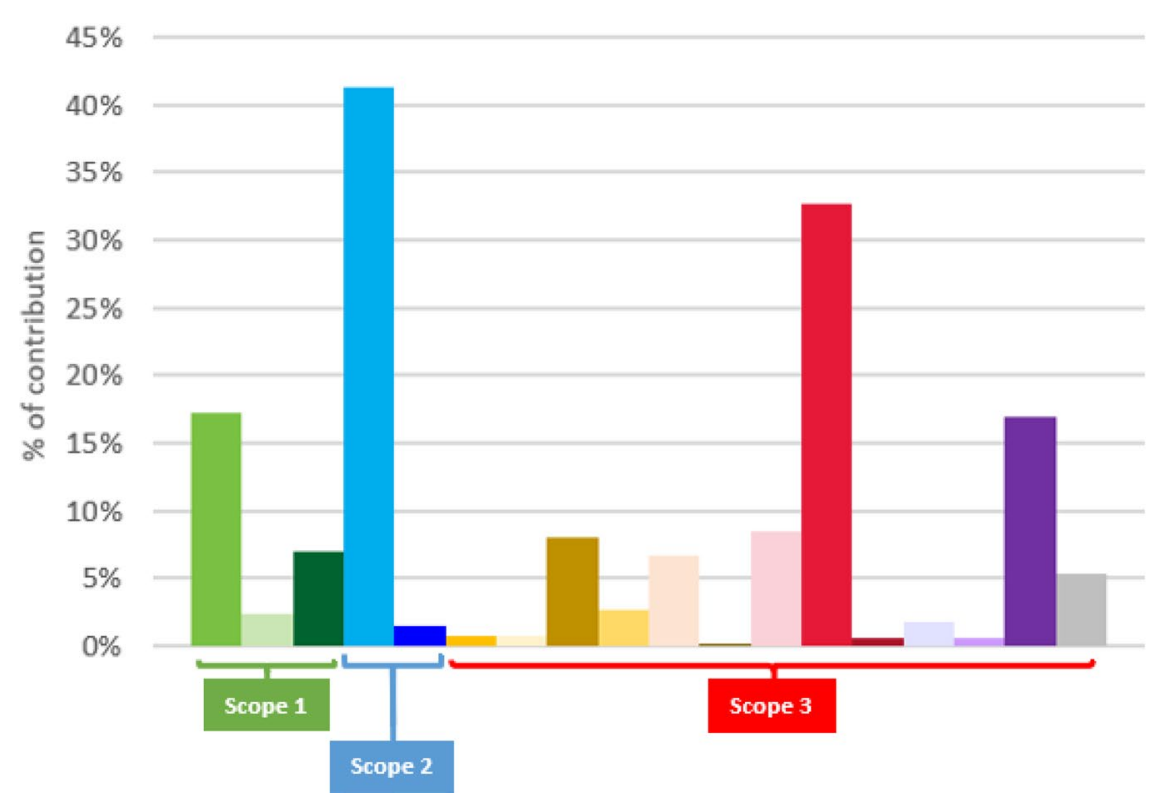

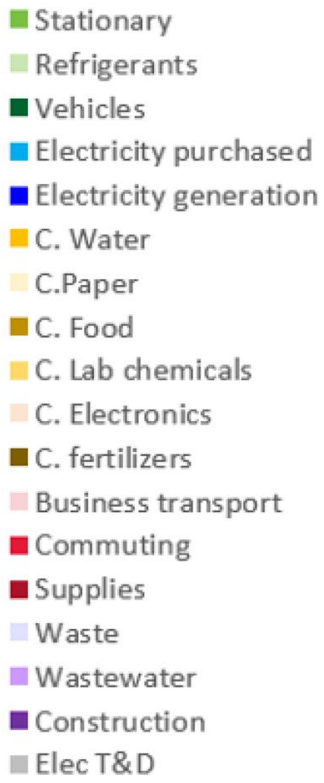

Fig. 7 Contribution of emission sources

\section{Conclusion}

Footprint assessment increases the level of environmental awareness of the population and provides a baseline to measure the impact of future policies and technical measures to reduce consumption and its associated GHG emissions. The results of HEI carbon footprinting will increase environmental awareness in the student population, which could then spill over to the larger population. With this goal in mind, the number of HEI that calculate their CF is gradually increasing and this sector has been able to reduce its environmental impact while increasing its efficiency.

This study conducted a global literature review focussed on carbon footprint analyses in the HEI sector and also pinpointed the main gaps in the literature. Although several standards have been developed in response to the need for transparency in reporting GHG emissions, there is no internationally accepted method for measuring, reporting and verifying offsets of GHG emissions from HEIs in a consistent and comparable way. Consequently, carbon footprint studies often yield widely divergent results and comparison of the CF of HEI is difficult. Indeed, even after normalising differences in the student population, the metric tons $\mathrm{CO} 2$-e per student varied between the HEI that were compared. This may be due to the time period considered, taking different methodologies or tools into account, the fact that each of them have incorporated different GHG emission sources in their scopes or have used different methods to obtain activity data, and even due to the use of specific/generic emission factors for each source. In addition, the application of action plans and offsetting projects to compensate the $\mathrm{CF}$ can also contribute to the differences in the $\mathrm{CF}$ from one university to another.

Hence, this study illustrates the importance of developing comprehensive and consistent GHG inventories for HEI, listing the GHG emission sources included and the factor emissions considered so that HEI is not compared unfairly.

Moreover, the findings demonstrated the importance of taking the Scope 3 emissions into account when analysing the carbon footprints of HEIs, because carbon emissions related to Scopes 2 and 3 correspond to the major portion of total emissions of the sector. For example, emissions associated with commuting by employees and students are often considered a significant carbon emitter, but are not always included as they are optional.

Therefore, after this review, it can be concluded that there are no standardised criteria for reporting the GHG emissions of universities or higher education centres, mainly with regard to aspects related to organisational boundaries for scope 3 emissions and emission factors. The absence of common criteria results in inventories that, apart from problems of comparability, do not indicate clearly the possible opportunities for mitigation actions.

For this reason, and as a futures research proposal, it is necessary to develop methodologies and a simplified tool for calculating the carbon footprint of HEI. The goal is to obtain results that can be compared with other universities and that all opportunities for reducing emissions can be identified and considered. 
Acknowledgements The authors are grateful to Ministerio de Ciencia, Innovación y Universidades (Spain) (DPI2017-89451-R and FPU18/02816).

\section{References}

AASHE (2005) Association for the advancement of sustainability in higher education

ACUPCC (2007) American College and University President's Climate Commitment

Almufadi FA, Irfan MA (2016) Initial estimate of the carbon footprint of Qassim university, Saudi Arabia. Int J Appl Eng Res 11:8511-8514

Alshqaqeeq F, Amin Esmaeili M, Overcash M, Twomey J (2020) Quantifying hospital services by carbon footprint: a systematic literature review of patient care alternatives. Resour Conserv Recycl. https://doi.org/10.1016/j.resconrec.2019.104560

Alvarez S, Blanquer M, Rubio A (2014) Carbon footprint using the compound method based on financial accounts. The case of the School of Forestry Engineering, Technical University of Madrid. J Clean Prod 66:224-232. https://doi.org/10.1016/j.jclepro.2013. 11.050

Baboulet O, Lenzen M (2010) Evaluating the environmental performance of a university. J Clean Prod 18:1134-1141. https://doi.org/ 10.1016/j.jclepro.2010.04.006

Bailey G, LaPoint T (2016) Comparing greenhouse gas emissions across Texas universities. Sustain 8:1-24. https://doi.org/10.3390/ su8010080

Barros MV, da Silva BPA, Piekarski CM et al (2018) Carbon footprint of transportation habits in a Brazilian university. Environ Qual Manag 28:139-148. https://doi.org/10.1002/tqem.21578

Beardsley R, Morton S (2009) Determining the greenhouse-gas impact of university-sponsored air travel. Am Soc Eng Educ 14:437

Brade W, Brade E (2014) Carbon $(\mathrm{CO}<\inf >2</ \mathrm{inf}>)$-footprint for milk and milk products (review). Tierarztl Umsch 69:167-176

Budihardjo MA, Syafrudin S, Putri SA et al (2020) Quantifying carbon footprint of Diponegoro University: non-academic sector. IOP Conf Ser Earth Environ Sci. https://doi.org/10.1088/1755-1315/ $448 / 1 / 012012$

Butt ZH (2012) Greenhouse gas inventory at an institution level: a case study of Massey University, New Zealand. Greenh Gas Meas Manag 2:178-185. https://doi.org/10.1080/20430779.2012. 760157

CA-CP (2020) Clean air cool planet carbon calculator

CC (2015) Carbon commitment

Chung CY, Miaw CL, Huang YC et al (2014) Investigation of carbon footprint on campus - a case study of Tajen University. Adv Mater Res 962-965:1495-1499

Clabeaux R, Carbajales-Dale M, Ladner D, Walker T (2020) Assessing the carbon footprint of a university campus using a life cycle assessment approach. J Clean Prod 273:122600. https://doi.org/ 10.1016/j.jclepro.2020.122600

COM 640 (2019) The European Green Deal. Communication from the Commission to the European Parliament, the European Council, the Council, the European Economic and Social Committee and the Committee of the Regions

COM 80 (2020) Regulation of the European Parliament and the Council establishing the framework for achieving climate neutrality and amending Regulation (EU) 2018/1999 (European Climate Law)

Copernicus (1993) Cre-Copernicus University Charta

Cordero EC, Centeno D, Todd AM (2020) The role of climate change education on individual lifetime carbon emissions. PLoS ONE 15:1-23. https://doi.org/10.1371/journal.pone.0206266
Cornejo PK, Santana MVE, Hokanson DR et al (2014) Carbon footprint of water reuse and desalination: a review of greenhouse gas emissions and estimation tools. J Water Reuse Desalin 4:238-252. https://doi.org/10.2166/wrd.2014.058

Criollo NP, Superior E, Superior E, et al (2019) The role of higher education institutions regarding climate change: the case of Escuela superior politécnica del litoral and its carbon footprint in Ecuador. In: International mechanical engineering congress and exposition IMECE2019. pp 1-10

CRUE (2002) Sectorial commission on CRUE sustainability

Durojaye O, Laseinde T, Oluwafemi I (2020) A descriptive review of carbon footprint

EIO-LCA (2020) Economic input-output life cycle assessment

Fenner AE, Kibert CJ, Woo J et al (2018) The carbon footprint of buildings: a review of methodologies and applications. Renew Sustain Energy Rev 94:1142-1152. https://doi.org/10.1016/j.rser. 2018.07.012

Filimonau V, Archer D, Bellamy L et al (2021) The carbon footprint of a UK University during the COVID-19 lockdown. Sci Total Environ 756:143964. https://doi.org/10.1016/j.scitotenv.2020.143964

GHG Protocol (2004) The greenhouse gas protocol

Gómez N, Cadarso MÁ, Monsalve F (2016) Carbon footprint of a university in a multiregional model: the case of the University of Castilla-La Mancha. J Clean Prod 138:119-130. https://doi.org/ 10.1016/j.jclepro.2016.06.009

GreenMetric U (2010) UI GreenMetric world university ranking on sustainability

Grimm D, Weiss D, Erek K, Zarnekow R (2014) Product carbon footprint and life cycle assessment of ICT-literature review and state of the art. In: Proceedings of the Annual Hawaii international conference on system sciences. pp 875-884

Gu Y, Wang H, Xu J et al (2019) Quantification of interlinked environmental footprints on a sustainable university campus: a nexus analysis perspective. Appl Energy 246:65-76. https://doi.org/10. 1016/j.apenergy.2019.04.015

Güereca LP, Torres N, Noyola A (2013) Carbon Footprint as a basis for a cleaner research institute in Mexico. J Clean Prod 47:396-403. https://doi.org/10.1016/j.jclepro.2013.01.030

GUPES (2012) Global universities partnership on environment for sustainability

Heinonen J, Ottelin J, Ala-Mantila S et al (2020) Spatial consumptionbased carbon footprint assessments-a review of recent developments in the field. J Clean Prod. https://doi.org/10.1016/j.jclep ro.2020.120335

IELab (2020) Australian ecology laboratory

IPCC Guidelines (2006) Guideliness for national greenhouse gas inventories. General guidance and reporting

ISCN (2007) International sustainable campus network

Iskandar J, Rahma N, Rosnarti D, Purnomo AB (2020) The carbon footprint of Trisakti University's campus in Jakarta, Indonesia. IOP Conf Ser Earth Environ Sci 452:1-9. https://doi.org/10.1088/ $1755-1315 / 452 / 1 / 012103$

ISO/TR 14069 (2013) Greenhouse gases. quantification and reporting of greenhouse gas emissions for organizations. guidance for the application of ISO 14064-1

ISO 14040 (2006) Environmental management. life cycle assessment. principles and framework

ISO 14064-1 (2006) Greenhouse gases-specification with guidance at the organizational level for quantification and reporting of greenhouse gas emissions and removals

Jarillo MP, Pedraza L, Ger PM, Bocos E (2019) Challenges of online higher education in the face of the sustainability objectives of the united nations: carbon footprint, accessibility and social inclusion. Sustain 11:1-15. https://doi.org/10.3390/su11205580

Jung J, Ha G, Bae K (2016) Analysis of the factors affecting carbon emissions and absorption on a university campus-focusing on 
Pusan National University in Korea. Carbon Manag 7:55-65. https://doi.org/10.1080/17583004.2016.1166426

Kandananond K (2017) The greenhouse gas gccounting of a public organization: the case of a public university in Thailand. Energy Procedia 141:672-676. https://doi.org/10.1016/j.egypro.2017.11. 091

Klein-Banai C, Theis TL, Brecheisen TA, Banai A (2010) A Greenhouse gas inventory as a measure of sustainability for an urban public research university. Environ Pract 12:35-47. https://doi. org/10.1017/S1466046609990524

Kulsuwan P, Sirisathit P, Srisuwan C (2019) The carbon footprint assessment from electricity of undergraduate students at Mahidol University Amnatcharoen Campus for Eco University. Int J Agric Technol 15:925-932

Kyoto Protocol (2008) Kyoto Protocol. Reference manual. On accounting of emissions and assigned amount

Laingoen O, Kongkratoke S, Dokmaingam P (2016) Energy consumption and greenhouse gas emission evaluation scenarios of Mea Fah Luang University. MATEC Web Conf 77:1-5. https://doi.org/10. 1051/matecconf/20167706007

Larsen HN, Pettersen J, Solli C, Hertwich EG (2013) Investigating the carbon footprint of a university - the case of NTNU. J Clean Prod 48:39-47. https://doi.org/10.1016/j.jclepro.2011.10.007

Letete TCM, Mungwe NW, Guma M, Marquard A (2011) Carbon footprint of the University of Cape Town. J Energy South Africa 22:2-12. https://doi.org/10.17159/2413-3051/2011/v22i2a3208

Mendoza-Flores R, Quintero-Ramírez R, Ortiz I (2019) The carbon footprint of a public university campus in Mexico City. Carbon Manag 10:501-511. https://doi.org/10.1080/17583004.2019. 1642042

Moerschbaecher M, Day JW (2010) The greenhouse gas inventory of Louisiana State University: a case study of the energy requirements of public higher education in the United States. Sustainability 2:2117-2134. https://doi.org/10.3390/su2072117

Naderipour A, Abdul Z, Rai M et al (2021) Assessment of carbon footprint from transportation, electricity, water, and waste generation: towards utilisation of renewable energy sources. Clean Technol Environ Policy 23:183-201. https://doi.org/10.1007/ s10098-020-02017-4

Navarro A, Puig R, Fullana-i-palmer P (2017) Science of the total environment product vs corporate carbon footprint: some methodological issues. A case study and review on the wine sector. Sci Total Environ 581-582:722-733. https://doi.org/10.1016/j.scito tenv.2016.12.190

Nijdam D, Rood T, Westhoek H (2012) The price of protein: Review of land use and carbon footprints from life cycle assessments of animal food products and their substitutes. Food Policy 37:760-770. https://doi.org/10.1016/j.foodpol.2012.08.002

Nilsson AE, Aragonés MM, Torralvo FA et al (2017) A review of the carbon footprint of $\mathrm{Cu}$ and $\mathrm{Zn}$ production from primary and secondary sources. Minerals 7:1-12. https://doi.org/10.3390/min70 90168

Ologun OO, Wara ST (2014) Carbon footprint evaluation and reduction as a climate change mitigation tool-case study of federal university of agriculture abeokuta, Ogun State, Nigeria. Int J Renew Energy Res 4:176-181. https://doi.org/10.20508/ijrer.74872

Onat NC, Kucukvar M (2020) Carbon footprint of construction industry: a global review and supply chain analysis. Renew Sustain Energy Rev 124:109783. https://doi.org/10.1016/j.rser.2020. 109783

Ozawa-Meida L, Brockway P, Letten K et al (2013) Measuring carbon performance in a UK University through a consumption-based carbon footprint: De Montfort University case study. J Clean Prod 56:185-198. https://doi.org/10.1016/j.jclepro.2011.09.028

PAS 2050 (2011) Specification for the assessment of the life cycle greenhouse gas emissions of goods and services
PAS 2060 (2014) Specification for the demonstration of carbon neutrality. Br Stand Inst

Pérez-Neira D, Rodríguez-Fernández MP, Hidalgo-González C (2020) The greenhouse gas mitigation potential of university commuting: a case study of the University of León (Spain). J Transp Geogr 82:102550. https://doi.org/10.1016/j.jtrangeo.2019.102550

Pirlo G (2012) Cradle-to-farmgate analysis of milk carbon footprint: a descriptive review. Ital J Anim Sci 11:109-118. https://doi.org/ 10.4081/ijas.2012.e20

Pre Consultants (2019) SimaPro software

Purwanto A, Syafrudin S, Sunarsih S (2019) Carbon footprint from settlement activities : a literature review. 2001:1-5

Quintero-Núñez M, López-Millán MC, Bisegna F et al (2015) Carbon and ecological footprints: tools for measuring the sustainability of the Institute of Engineering at the UABC, Mexicali, BC, Mexico. WIT Trans Ecol Environ 199:3-13. https://doi.org/10. 2495/RAV150011

Rao P, Krishnamurthy S, Pradhan V (2017) Commuters' carbon footprints: a sustainability case study from Symbiosis International University, India. In: Higher Education Institutions in a Global Warming World-The transition of Higher Education Institutions to a Low Carbon Economy. pp 37-57

Ridhosari B, Rahman A (2020) Carbon footprint assessment at Universitas Pertamina from the scope of electricity, transportation, and waste generation: toward a green campus and promotion of environmental sustainability. J Clean Prod 246:119172. https:// doi.org/10.1016/j.jclepro.2019.119172

Riedy C, Daly J (2010) Targeting a low-carbon university: a greenhouse gas reduction target for the Australian Technology Network of Universities. Univ Clim Chang 1:151-162. https://doi.org/10. 1007/978-3-642-10751-1

Rizan C, Steinbach I, Nicholson R et al (2020) The carbon footprint of surgical operations: a systematic review. Ann Surg 272:986-995. https://doi.org/10.1097/SLA.0000000000003951

Robinson O, Kemp S, Williams I (2015) Carbon management at universities: a reality check. J Clean Prod 106:109-118. https://doi. org/10.1016/j.jclepro.2014.06.095

Robinson OJ, Tewkesbury A, Kemp S, Williams ID (2018) Towards a universal carbon footprint standard: a case study of carbon management at universities. J Clean Prod 172:4435-4455. https://doi. org/10.1016/j.jclepro.2017.02.147

Rodríguez-Andara A, Río-Belver RM, García-Marina V (2020) Sustainable university institutions: Determination of gases greenhouse efect in a university center and strategies to decrease them. Dyna 95:47-53. https://doi.org/10.6036/9247

Rugani B, Vázquez-rowe I, Benedetto G, Benetto E (2013) A comprehensive review of carbon footprint analysis as an extended environmental indicator in the wine sector. J Clean Prod 54:61-77. https://doi.org/10.1016/j.jclepro.2013.04.036

Sangwan KS, Bhakar V, Arora V, Solanki P (2018) Measuring carbon footprint of an Indian university using life cycle assessment. Procedia CIRP 69:475-480. https://doi.org/10.1016/j.procir.2017. 11.111

Santovito RF, Abiko AK (2018) Recommendations for preparation of anthropogenic greenhouse gases emission inventory for University Campuses. World Sustain Ser. https://doi.org/10.1007/978-3-31976885-4_19

Schwartz Y, Raslan R, Mumovic D (2018) The life cycle carbon footprint of refurbished and new buildings-a systematic review of case studies. Renew Sustain Energy Rev 81:231-241. https://doi. org/10.1016/j.rser.2017.07.061

Schwarz M, Bonhotal J (2018) Carbon footprint of a university compost facility: case study of Cornell farm services. Compost Sci Util 26:128-143. https://doi.org/10.1080/1065657X.2018. 1438934 
Sinha P, Schew WA, Sawant A et al (2010) Greenhouse gas emissions from U.S. institutions of higher education. J Air Waste Manag Assoc 60:568-573. https://doi.org/10.3155/1047-3289.60.5.568

Sippel M, Meyer D, Scholliers N (2018) What about greenhouse gas emissions from students? An analysis of lifestyle and carbon footprints at the University of Applied Science in Konstanz, Germany. Carbon Manag 9:201-211. https://doi.org/10.1080/17583 004.2018.1440851

Song G, Che L, Zhang S (2016) Carbon footprint of a scientific publication: a case study at Dalian University of Technology, China. Ecol Indic 60:275-282. https://doi.org/10.1016/j.ecolind.2015. 06.044

STARS (2013) Sustainability monitoring, assessment and rating system

Stephan A, Muñoz S, Healey G, Alcorn J (2020) Analysing material and embodied environmental flows of an Australian university-towards a more circular economy. Resour Conserv Recycl 155:104632. https://doi.org/10.1016/j.resconrec.2019.104632

Sun YY, Cadarso MA, Driml S (2020) Tourism carbon footprint inventories: a review of the environmentally extended input-output approach. Ann Tour Res 82:102928. https://doi.org/10.1016/j. annals.2020.102928

Syafrudin S, Zaman B, Budihardjo MA et al (2020) Carbon footprint of academic activities: a case study in Diponegoro University. IOP Conf Ser Earth Environ Sci 448:012008. https://doi.org/10.1088/ $1755-1315 / 448 / 1 / 012008$

TD (1990) Talloires declaration

THE (2004) Times higher education-World University Ranking

Thurston M, Eckelman MJ (2011) Assessing greenhouse gas emissions from university purchases. Int J Sustain High Educ 12:225-235. https://doi.org/10.1108/14676371111148018
Townsend J, Barrett J (2015) Exploring the applications of carbon footprinting towards sustainability at a UK university: reporting and decision making. J Clean Prod 107:164-176. https://doi.org/ 10.1016/j.jclepro.2013.11.004

Ullah I, Islam-Ud-Din HU et al (2020) Carbon footprint as an environmental sustainability indicator for a higher education institution. Int J Glob Warm 20:277-298. https://doi.org/10.1504/JJGW.2020. 107147

Umberto (2020) LCA software-Umberto LCA

Varón-hoyos M, Osorio-tejada J, Morales-pinzón T et al (2021) Carbon footprint of a university campus from Colombia. Carbon Manag. https://doi.org/10.1080/17583004.2021.1876531

Vásquez L, Iriarte A, Almeida M, Villalobos P (2015) Evaluation of greenhouse gas emissions and proposals for their reduction at a university campus in Chile. J Clean Prod 108:924-930. https:// doi.org/10.1016/j.jclepro.2015.06.073

Wahid MFHC (2019) Review on the method for carbon footprint calculation of highway development. Rev Method Carbon Footprint Calc Highway Dev. https://doi.org/10.1088/1757-899X/513/1/ 012001

Yañez P, Sinha A, Vásquez M (2020) Carbon footprint estimation in a university campus: evaluation and insights. Sustain 12:1-15. https://doi.org/10.3390/SU12010181

Yazdani Z, Talkhestan GA, Kamsah MZ (2013) Assessment of carbon footprint at University Technology Malaysia (UTM). Appl Mech Mater 295-298:872-875

Publisher's Note Springer Nature remains neutral with regard to jurisdictional claims in published maps and institutional affiliations. 